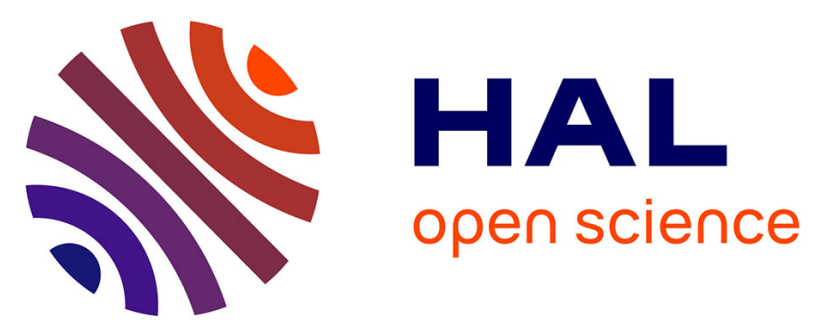

\title{
Environmental influences on crustacean sex determination and reproduction: environmental sex determination, parasitism and pollution
}

Alison M. Dunn, Thierry Rigaud, Alex T. Ford

\section{- To cite this version:}

Alison M. Dunn, Thierry Rigaud, Alex T. Ford. Environmental influences on crustacean sex determination and reproduction: environmental sex determination, parasitism and pollution. R.D. Cothran; M. Thiel. The Natural History of the Crustacea: Reproductive Biology, 6, Oxford University Press, pp.394-428, 2020, 9780190688554. 10.1093/oso/9780190688554.003.0014 . hal-02521880

\author{
HAL Id: hal-02521880 \\ https://hal.science/hal-02521880
}

Submitted on 10 Nov 2020

HAL is a multi-disciplinary open access archive for the deposit and dissemination of scientific research documents, whether they are published or not. The documents may come from teaching and research institutions in France or abroad, or from public or private research centers.
L'archive ouverte pluridisciplinaire HAL, est destinée au dépôt et à la diffusion de documents scientifiques de niveau recherche, publiés ou non, émanant des établissements d'enseignement et de recherche français ou étrangers, des laboratoires publics ou privés.

\section{(ㄷ)(1) $\$$}

Distributed under a Creative Commons Attribution - NonCommerciall 4.0 International 
Chapter 14. Environmental Influences on Crustacean Sex Determination and

Reproduction: Environmental Sex determination, Parasitism and Pollution.

Alison M. Dunn, Thierry Rigaud, and Alex T. Ford 
$<1>$ Abstract

This chapter reviews the influences of environmental factors on sex determination, sex ratios, and reproductive behavior in the Crustacea, focusing in particular on amphipod and isopod examples. A range of abiotic and biotic environmental factors influence reproduction in Crustacea including temperature, day length, pollutants, and parasites. Individual crustaceans may benefit from these environmental influences, but in other cases, reproductive biology responses to biotic and abiotic environments may be detrimental to individual fitness. Environmental Sex Determination (ESD) falls into the former category. ESD is an adaptive mechanism of sex determination that is rare, but has evolved in diverse taxa. Evidence from gammarid amphipods is used to explore the evolution of ESD in response to a patchy environment. While ESD is an adaptive mechanism of sex determination, the impact of other environmental factors can be very costly. Parasitic castrators can lead to a reduction or total cessation of reproduction in crustacean hosts, driving population declines. In contrast, parasitic feminisers convert male hosts into females, enhancing maternal parasite transmission but also leading to sex ratio distortion in the host population. We discuss parasite-host coevolutionary conflict and review evidence that selection on the host in response to parasitic sex ratio distortion has led to altered mate choice in amphipods, and to the evolution of a novel system of sex determination in isopods. Human-induced environmental influences can also be seen in Crustacea, and we discuss how parasites, ESD, and endocrine-disrupting chemicals can each affect sex determination and lead to abnormal intersex phenotypes. We end by highlighting areas for future research on the diverse world of crustacean reproduction.

$<1>$ Introduction

Reproduction in the Crustacea is under the influence of a range of environmental factors that affect sex determination, sex ratios, and reproductive behavior. In this chapter, we review the 
impact of environmental factors on Crustacea, focusing in particular on amphipod and isopod examples. The majority of crustaceans, including amphipods and isopods, reproduce sexually and have separate sexes, with the sex of an individual being genetically controlled. However, in some species of gammarid amphipods, sex is not solely genetically determined, but instead is determined by the environmental conditions experienced during development (Environmental Sex Determination, or ESD). In the first section of this chapter, we discuss this unusual method of sex determination, its advantages and its evolutionary significance. Crustacean reproduction is also influenced by other biotic and abiotic environmental factors, in particular, parasitism and pollution. In contrast with ESD, which is an adaptive mechanism of sex determination, these other environmental influences on reproduction are often costly.

Parasitic castration is widespread in crustaceans and is very costly as it can lead to partial or complete loss of reproduction, and we describe the mechanisms of castration, and the evolutionary significance for the parasite and its crustacean host.

Amphipods and isopods are also hosts to parasites that change the sex of their host. These parasitic sex ratio distorters are only transmitted by female hosts and have evolved to feminize their hosts, thereby increasing their own transmission. We compare parasitic sex ratio distortion by bacteria and microsporidian parasites that infect isopod and amphipod hosts, and review the evolutionary conflict between sex ratio distorters and their hosts.

Crustaceans are the most successful taxonomic group of aquatic invaders globally (Karatayev et al. 2009), with widespread impacts on biodiversity, and we consider situations where parasite manipulation of host reproduction may influence the success and impact of biological invasions.

Intersexuality is the abnormal condition where individuals from gonochoristic species have both male and female characteristics and is widespread in the Crustacea, and we 
highlight the different types of intersexuality and the environmental factors that lead to intersex phenotypes. We review evidence for multiple causes of intersexuality including incomplete male development under ESD, partial feminization by parasites, and the effect of endocrine disrupting pollutants.

\section{$<1>$ Environmental Sex Determination in the Amphipoda}

The most common system of sex determination among gonochoristic species is genetic sex determination, exemplified by the XX (female) XY (male) system found in mammals. However, a few species display Environmental Sex Determination (ESD). ESD is a mechanism of sex determination in which sex is determined after conception in response to environmental conditions experienced by the developing offspring. Although it is rare, ESD has evolved in diverse taxa; it has been documented in species from several phyla including chordates (fish and reptiles; Warner and Shine 2008, Conover 1984), nematodes, annelids, and arthropods (crustaceans; Adams et al. 1987, Korpelainen 1990). It may occur in one species but be absent from closely related taxa (Korpelainen 1990), and populations within a species may differ in the presence or absence and prevalence of ESD (Dunn et al. 2005, Duffy et al. 2015). What factors drive the evolution and maintenance of this unusual mechanism of sex determination?

For some species, the selective forces behind ESD remain a matter of debate. Theoretical work by Charnov and Bull (1977) proposed that ESD should be selected over genetic sex determination in situations where offspring enter a patchy environment, and when patch quality has a differential effect on the fitness of male and female offspring. By using environmental cues for sex determination, offspring are able to develop into the sex that will benefit more from the patch type in which it was born. Empirical evidence for the adaptive 
significance of this mode of sex determination has been well illustrated for some species of vertebrates.

Among the invertebrates, ESD is known in a few species belonging to diverse crustacean groups (Amphipoda, see references below; Copepoda, see Becheikh et al. 1998; and Cirripedia, see Hoeg et al. 2016). The example of the extensively-studied amphipod Gammarus duebeni illustrates the adpative significance of ESD (Bulnheim 1978, Naylor et al. 1988, Dunn et al. 2005). In G. duebeni, sex determination is cued by the photoperiod and temperature experienced by the developing young three to four weeks after release from the mother's brood pouch (Bulnheim 1978, Naylor et al. 1988, Dunn et al. 2005). As a result, most of the young produced early in the breeding season become male, and young produced later in the breeding season become female (Dunn et al. 2005). ESD is adaptive in G. duebeni because the environment is temporally patchy: animals born earlier in the breeding season achieve a larger adult size, and size affects the fitness of both males and females but has a greater effect on males (Adams et al. 1987, McCabe and Dunn 1997). This size advantage is evident during precopulatory mate guarding. A male will guard a female for several days before her molt, using his anterior gnathopods to carry her beneath his ventral surface until she oviposits, which is when copulation takes place. Guarding has evolved in response to a male-biased operational sex ratio (Grafen and Ridley 1983); males are able to mate at any point (other than when they are molting), but female oogenesis is synchronised with the molt cycle, and oocytes are released into the brood pouch at molt. By guarding a female for the days leading up to her molt, the male ensures that he is able to copulate with her when she molts and lays her eggs into the brood pouch. Males compete for the females they guard in precopula (Naylor and Adams 1987) and larger males can guard larger females (that produce more eggs), while small males may fail to mate (McCabe and Dunn 1997). In contrast, although fecundity is size-dependent, females suffer less from being of small size as they are 
still able to find mates, while very large females may fail to mate if there is only a small pool of males large enough to guard them (Hatcher and Dunn 1997, McCabe and Dunn 1997). Hence, it is more advantageous for offspring released early in the season to become males than females. Under ESD, temperature and day length are used to cue sex determination and hence to match an individual's sex to its potential size-related fitness. ESD in Gammarus duebeni is thus an adaptive response to a temporally patchy environment. In contrast, ESD in the parasitic copepod Pachypygus gibber is an adaptive response to a spatially patchy environment and to sexual selection. This copepod feeds on plankton filtered by its sea squirt (Ciona intestinalis) host and has three sexual morphs; females, typical males and atypical males, with only atypical males able to swim between hosts. In this species, sex determination is cued by food availability and social cues (mate availability and intrasexual competition) When resources are plentiful, female sex determination is cued, although typical males may develop if a female is already present in the host, thus increasing the likelihood of finding a partner. Under poor resources, males are produced. Furthermore, atypical, swimming males are more likely to occur in the presence of other males, an adaptive response to avoid local mate competition (Becheikh et al 1998). These parallel examples illustrate the flexibility of ESD as a response to maximise reproductive success in a patchy environment.

The mechanism of ESD in crustaceans has not been elucidated. In Crustacea, male sexual differentiation is under the control of the androgenic gland (Charniaux-Cotton and Payen 1985, Katakura 1989, López Greco 2013). In G. duebeni, the time window of three to four weeks post-release, during which the young are responsive to environmental cues for sex determination, corresponds to the period of androgenic gland differentiation, suggesting that environmental cues modify androgenic gland differentiation (Naylor et al. 1988).

There have been few studies that tested for ESD in other amphipods. ESD cued by photoperiod has been demonstrated for G. zaddachi (Bulnheim 1978) and Echinogammarus 
marinus (Guler et al. 2012) but Bulnheim (1978) found no evidence for ESD in G. locusta, suggesting that this strategy of sex determination may have evolved multiple times amongst amphipods. There is also strong evidence for between population variation in both the degree of ESD and in the cues used for sex determination in G. duebeni: while sex is cued by photoperiod alone in some populations, animals from more northern populations respond to an interaction between day length and temperature (Dunn et al. 2005). This variation among populations reflects local adaptation to the different environments experienced during the breeding seasons by these populations. In Northern populations, where the breeding season is short and there are no overlapping generations, low temperatures and short day length at the start of the breeding season induce male-biased sex ratios. This is adaptive, because earlyborn males will maximize the advantages of long growth. In other populations, with longer reproductive season, selection for ESD is less strong as females produced early in a given year can reach sexual maturity during the same year and can mate with males born during the previous year (Dunn et al. 2005). A similar pattern is observed in the fish Menidia menidia, in which the level of temperature-controlled sex determination is also driven by the length of the growing season (Duffy et al. 2015).

\section{$<1>$ Parasitism, Sex Determination and Reproductive Behavior}

The environment in which individuals are living is not restricted to abiotic factors such as temperature or photoperiod. A major component of the environment is other species, and, among these interacting species, parasites represent a major selective pressure on the organisms they infect. There is now growing evidence that parasitism may influence sex determination and reproduction and this has been extensively demonstrated among the Crustacea. In this section, we explore the impact of parasitic castrators and of parasitic sex 
ratio distorters and the conflict between parasite and crustacean host for sex determination and reproductive behavior.

\section{$<2>$ Parasitic Castration in Crustacea}

Numerous parasites are able to prevent or block the reproduction of their hosts (reviews in Reinhard 1956, Baudoin 1975, Lafferty and Kuris 2009). Since the publication of the seminal papers of Kuris (1974) and Baudoin (1975), castration has been considered an adaptive trophic strategy of the parasite, in which the parasite partially or wholly eliminates host reproduction to acquire energy and nutrients (Lafferty and Kuris 2009). In other words, a parasitic castrator will prevent host reproduction and will hijack the energy normally invested in host's reproduction for its own growth and reproduction. However, an alternative hypothesis is that reduced reproduction may be an adaptive host strategy that reallocates remaining available energy from reproduction to maintenance (limiting the damage from infection) or longevity, increasing the probability for future reproduction following recovery from the infection (Hurd 2001). In this section, we review the mechanisms, evolutionary significance and ecological impact of parasitic castration.

Parasitic castration has been reported in the majority of crustacean taxa, and the parasite taxa causing castration are also very diverse, ranging from bacteria to other crustaceans (Table 14.1). Indeed, the diversity of parasites is probably greater than reported here, since, with a few exceptions, such as the commercial Decapoda or Paguroidea, the species composition of parasites in most crustacean taxa is not well studied. The intensity or nature of castration varies. In most reported cases, total castration is associated with infection (Table 14.1), with parasite growth or multiplication resulting in gonad degeneration or destruction. In other cases, infected individuals reproduce but their fecundity is lowered (referred to as "reduction in fertility or fecundity" in Table 14.1). Finally, "behavioral" castration has been 
reported, where infected individuals show a dramatically reduced inclination to pair or mate, although no obvious damage of gonads was observed. The type of castration is often very specific to the host-parasite association. A single host species may be castrated differently according to the parasite species it harbors, even if these parasites are phylogenetically closely related. For example, the cestodes Flamingolepis flamingo and F. liguloides are both castrators of the intermediate host, the brine shrimp Artemia parthenogenetica; in contrast, $F$. tadornae does not affect Artemia reproduction (Sanchez et al. 2012). The same kind of specificity in the nature of castration has been observed between two acanthocephalan parasite species infecting the same amphipod host, Gammarus pulex; female hosts infected by Polymorphus minutus suffer total castration, whereas those infected with Pomphorhynchus laevis show only reduced fecundity (Bollache et al. 2002). [Fig. 14.1 near here]

\section{<3> Mechanisms of Parasitic Castration}

With a few exceptions, mechanisms of parasitic castration remain poorly understood. The most obvious way for a parasite to castrate a host is to directly destroy or consume the gonads. Such a mechanism is known in anther-smut fungus infecting plants (where the fungi spores replace host gametes) and in trematodes infecting snails (e.g., Jokela et al. 1993, Sloan et al. 2008), but has not been demonstrated in crustacean hosts. This could be due to the difficulty of discriminating between direct consumption of the gonads by parasites and indirect manipulation that diverts host resources away from gonads (Lafferty and Kuris 2009).

Energy drain by parasites is another possible mechanism of castration. Both hosts and parasites face resource limitation, and, by definition, a parasite diverts energy from the host for its own growth or reproduction. Since reproduction is an energetically demanding process, it may be the first physiological trait of the host affected by the parasite, resulting in castration. Examination of castration in the cladoceran Daphnia magna by its bacterial 
parasite Pasteuria ramosa (an obligate killer, therefore more a parasitoid than a parasite), revealed a progressive but rapid and irreversible cancellation of reproduction in Daphnia, associated with an increased growth rate (hence inducing gigantism; Ebert et al. 2004).

Resource diversion from host to parasite may be general, or may be targeted such that resources are diverted from reproductive organs of the hosts. Lafferty and Kuris (2009) proposed that parasites may specifically disrupt the biochemical mechanisms of vitellogenesis (in female hosts), allowing the redirection of nutritive yolk for their own benefit. Such a mechanism has been proposed for the acanthocephalan parasite Polymorphus minutus in its gammarid host Gammarus pulex (Bollache et al. 2002). Here, vitellogenesis disorders were observed, as well as abnormal maturation of the few developing oocytes (Fig. 14.1). Since gammarids transfer only astaxanthin to their eggs among all available carotenoids and because the parasite selectively accumulates astaxanthin from the host (Gaillard et al. 2004), redirection by the parasite of a specific host resource used in reproduction is a reasonable hypothesis for explaining castration. Different degrees of castration have been observed among acanthocephalan species that infect the same host species (Bollache et al. 2002), and the various species of acanthocephalans infecting G. pulex differ in their carotenoid contents (Perrot-Minnot et al. 2011), probably reflecting differences in the carotenoid uptake. Although a link between parasite species differences in the carotenoid uptake and variation in castration has not yet been tested, it is tempting to make a parallel between these two phenomena. [Fig. 14.1 near here]

Energy draining or energy reallocation, however, does not explain cases of irreversible degeneration of gonads. Such degeneration is better explained by specific humoral manipulation of the host endocrine system by parasites. This has been demonstrated in rhizocephalan parasites infecting various decapods. Crabs (e.g., Carcinus maenas) infected by rhizocephalans (e.g., Sacculina) cease reproduction following infection. Parasite organs called 
"roots" invade the general cavity and most organs of their hosts. In infected male crabs, spermatogenesis stops and the testes degenerate. These castrated males progressively differentiate feminized morphology; they acquire a broader and longer abdomen where the parasite's externa will develop in place of crab eggs (Kristensen et al. 2012). In parallel, infected males begin to exhibit behaviors of brooding typically exhibited by non-parasitized females (migrating where brooding females are present, and grooming the externa; Sloan 1984 and references therein). All these changes are due to disruption of the neuroendocrine system by a specific parasite product released by the parasite's roots (Rubiliani and Godette 1981, Rubiliani 1985).

\section{<3> Evolutionary Significance of Parasitic Castration}

Two contrasting evolutionary strategies have been proposed to explain the reduction or prevention of host reproduction by a parasite infection: a "parasite strategy", where the energy dedicated to host reproduction is diverted to parasite survival and fecundity (Baudoin 1975), or a "host strategy" of resource reallocation (Hurd 2001).

Host strategies could include a reallocation strategy, where, in theory, the energy remaining after parasite demand could be reallocated in the host from reproduction to survival (Hurd 2001) if host defenses involve the redirection of host resources away from reproduction and toward survival (Bonds 2006). Furthermore, when a host is infected by a castrating parasite, selection should favor reallocation of resources to reproduction in the period before parasitic castration takes effect, a strategy termed fecundity compensation. For example, Daphnia magna infected by the microsporidian Glugoides intestinalis produced first broods that were $40 \%$ larger than the first broods of uninfected controls.

There is also strong empirical evidence for castration as a parasite strategy. Daphnia magna infected by the bacterium Pasteuria ramosa (Ebert et al. 2004, Jensen et al. 2006) 
show castration associated with host gigantism. These traits benefit the parasite, because host reproductive resources are "converted" into the parasite's transmission stages. In addition, Duneau et al. (2012) showed that male and female Daphnia represent different environments for the parasite: host castration led to an increased carrying capacity for parasite proliferation in female but not male hosts. Here, castration evolved as an adaptation to exploit female hosts, the most abundant "resource" available for the parasite (D. magna are mostly parthenogenetic). Observations of behavioral and morphological changes induced by rhizocephalan parasites all suggest advantages for the parasite, but not for the decapod host (Sloan 1984, Kristensen et al. 2012). The development of a broader abdomen allows the parasite's externa to have more space and grooming behavior allows the externa to be oxygenated. To our knowledge, however, no firm experimental evidence for this has been provided.

The two hypotheses of host or parasite strategies are not mutually exclusive. For example, it appears that both parasite strategy and host compensation strategy occur in a Corophium/trematode relationship depending on host age (McCurdy et al. 1999). Older (already mated) females newly infected by trematodes often aborted and ate their young. This phenomenon is inconsistent with a host-compensation strategy because these old, overwintering females will die shortly after releasing their offspring, and the phenomenon likely reflects parasite manipulation. In contrast, young non-ovigerous females that were newly infected shortened the onset of their reproduction, a response compatible with fecundity compensation by the host to maximize reproduction before the onset of castration (McCurdy et al. 1999).

<3> Ecological Consequences of Parasitic Castration 
Because of their effect on host fecundity or survival, parasites are expected to suppress host population growth, density, or both (Anderson and May 1979, Dobson and Crawley 1994). Owing to their strong effect on host reproduction, this should be true for castrating parasites. An assemblage of eight parasites, all of which reduce the host's fecundity, decreased population density of their host, Daphnia magna, and the magnitude of this decrease was correlated with overall endoparasite prevalence (Decaestecker et al. 2005). Dumbauld et al. (2011) showed that the collapse of mud shrimp (Upogebia pugettensis) populations along the Pacific coast of North America may be caused by a sudden epidemic of an exotic, castrating bopyrid isopod parasite. The lack of co-evolutionary history between the host and this newly introduced parasite may explain why host populations suffer to such a great extent through castration by this parasite.

The effects on population dynamics of castrated hosts may also have cascading effects on other species in the ecological community, including consequences for competition between host species. The invasive American brine shrimp Artemia franciscana is known to outcompete European species such as A. parthenogenetica. Sanchez et al. (2012) showed that one important factor explaining this competitive advantage is the large impact of cestode parasites on the native, but not the invading species. In particular, the most prevalent parasite species, Flamingolepis liguloides, castrates A. parthenogenetica but not A. franciscana, contributing to the competitive advantage of the invasive A. franciscana. This example of parasite-driven apparent competition, as well as the example of the mud shrimp above, illustrates the importance of parasitism on the outcome of biological invasion success (Dunn 2009).

<2> Parasitic Sex Ratio Distortion in Crustacea 
In addition to castrating their host, parasites may influence host sex determination and differentiation to increase the parasite's fitness. By doing so, their impact on crustacean reproductive biology is important at both ecological and evolutionary scales. Reproductive parasites are microparasites that manipulate reproduction of the host (Bandi et al. 2001). Although this group of parasites is taxonomically diverse, they all are vertically transmitted from generation to generation of hosts via the gametes. Hence, in contrast with parasitic castrators, reproductive parasites rely directly on host reproduction for transmission via the oocytes to the next generation of hosts. Due to the difference in the size of male and female gametes, such transmission is mainly or solely maternal. As a result of this maternal transmission, a range of strategies have evolved among reproductive parasites, including cytoplasmic incompatibility and sex ratio distortion (by the means of parthenogenesis induction, male killing, and feminization), all of which benefit the parasite by increasing the relative frequency of female (transmitting) hosts. Among crustacean hosts, parasite-induced feminization is common and induced by parasitic fungi in the phylum Microsporidia in amphipod hosts and by bacteria of the genus Wolbachia in isopod hosts.

Feminizing Microsporidia were first described in the amphipod Gammarus duebeni (Bulnheim and Vavra 1968). Two species of Microsporidia have been well studied and shown to cause feminization in this host: Nosema granulosis (Terry et al. 1999a) and Dictyocoela duebenum (Terry et al. 2004). These parasites are characterized by low virulence, which is adaptive as the parasite depends on successful host reproduction to ensure transmission to the next generation of hosts. However, they cause feminization of the host, converting male offspring into females (Fig. 14.2. Such feminization is adaptive for the parasite as males are a transmission dead end (parasites are not transmitted via sperm). By converting male offspring into females, the parasite enhances its likelihood of transmission (via the oocytes) to the next host generation (Fig. 14.3). [Fig. 14.2 and 14.3 near here] 
Prevalence of these feminizing parasites varies between populations with $N$. granulosis prevalence ranging from $0-50 \%$ and $D$. duebenum from $7-45 \%$ in populations surveyed in the UK and France (Ironside et al. 2003). It also appears that the strategy of feminization is widespread among amphipod/microsporidian associations. A survey of amphipods from northern Europe detected vertically transmitted Microsporidia across all 16 amphipod species sampled, and sequences from 11 distinct parasite species were found. In five out of eight parasite species tested, infection was more frequent in female than male hosts, suggesting sex ratio distortion (although this has been experimentally tested and confirmed for only two of these five parasite species). Phylogenetic reconstruction revealed that these potential sex ratio distorters occurred in diverse lineages of the Microsporidia, suggesting that sex ratio distortion has independently evolved several times in Microsporidia/crustacean systems (Terry et al. 2004, see also Haine et al. 2004, Haine et al. 2007).

In the terrestrial isopod Armadillidium vulgare (woodlouse), populations exhibit strong female-biased sex ratios. In fact, numerous A. vulgare females produce highly female-biased broods without differential mortality between sexes. The causative agents of this maternallyinherited sex-ratio distortion are Wolbachia endosymbionts (Bouchon et al. 1998). Embryos that inherit Wolbachia develop a female phenotype regardless of their sex chromosome genotype (typically ZZ are males and ZW are females; Howard 1942, Rigaud 1997). One important outcome of Wolbachia infection is the counter selection of the W sex chromosome in populations harboring Wolbachia, because feminized ZZ individuals produce excess females without transmitting a W chromosome (Rigaud 1997, Caubet et al. 2000). In populations where Wolbachia is highly prevalent, this results in absence of W sex chromosome and sex determination is under the control of Wolbachia: individuals inheriting Wolbachia develop as females whereas males are uninfected individuals. Thus, the $A$. vulgare/Wolbachia model may be considered as an example of cytoplasmic sex determination 
(Cordaux et al. 2011). Different A. vulgare populations have been shown to harbor three Wolbachia variants, each exhibiting different transmission and/or feminization intensities (Cordaux et al. 2004, Verne et al. 2012). Furthermore, in addition to the Wolbachia, another non-Mendelian feminizing element (termed "f-factor") is present in various A. vulgare populations, also producing excesses of females but with a very complex pattern of inheritance and/or expression (Juchault et al. 1992, Rigaud et al. 1999a). It has been proposed that the f-factor could be a fragment of the Wolbachia chromosome carrying the bacterial feminizing information that has been inserted into the woodlouse genome (Juchault and Mocquard 1993). Recently, Leclerc et al. (2016) identified a 3-Mb insert of the feminizing Wolbachia genome transferred into the A. vulgare nuclear genome, confirming this hypothesis.

Populations of $A$. vulgare are not all entirely infected by Wolbachia bacteria, and, when the infection is present, a polymorphism of infection is always observed among females (Rigaud et al. 1999a, Verne et al. 2012). Conflict between parasite and host for control over host sex determination has led to the co-evolution of host resistance. Autosomal host gene(s) occur in some A. vulgare populations that confer resistance to Wolbachia transmission (Rigaud and Juchault 1992) or reduce the feminization efficiency of both f-factor and Wolbachia (Rigaud and Juchault 1993). The very complex sex determination in A. vulgare woodlice is thus an example of nucleo-cytoplasmic sex determination, and ultimately, theoretical models predict that the interplay between feminizers and autosomal resistance genes could lead to the evolution of sex chromosomes, autosomal chromosomes becoming new sex-determining chromosomes (Caubet et al. 2000). To sum up, the ancient infection by feminizing Wolbachia bacteria in A. vulgare induces nucleo-cytoplasmic conflicts and also creates evolutionary novelty, thus having a profound impact on the evolution of the isopod genetic sex determination. 
More widely, many isopods, as well as other crustaceans, carry Wolbachia symbionts (Bouchon et al. 1998, Cordaux et al. 2001, Cordaux et al. 2012, Zimmermann et al. 2015). Feminization is strongly suspected or demonstrated in some species (e.g., Bouchon et al. 1998, Rigaud et al. 1999b), with some documented cases of strongly female-biased population sex ratios (e.g., Moreau and Rigaud, 2003, Fig. 14.4). However, for many infected species, reproductive modifications leading to sex ratio distortion remain to be investigated (Cordaux et al. 2012, Zimmermann et al. 2015). [Fig. 14.4 near here]

$<3>$ Parasite Transmission and Feminisation

Feminizing parasites are under conflicting selective pressures with respect to parasite burden within the host. Selection should favor parasite replication to increase chances of infecting oocytes and subsequent transmission to new hosts, and to induce feminization of the new host (Terry et al. 1997, Dunn et al. 1998). However, these parasites rely on host reproduction for transmission and so selection should favor low replication and hence low burden-associated virulence (Bandi et al. 2001). As a result of these conflicting selective pressures on burden and virulence, feminizing parasites have evolved elegant strategies to target host tissues, yet cause low virulence.

Studies of two species of microsporidian feminisers, $N$. granulosis and D. duebenum infecting their amphipod host, G. duebeni, revealed that these parasites are localized in the gonadal tissue of the adult host (Dubuffet et al. 2013). Proliferation of the parasites and development of the infective spore occurs in the follicle cells (Fig. 14.5) that transfer components to the developing oocyte (López Greco 2013); spores then invade secondary oocytes during their maturation (Dubuffet et al. 2013). These feminizing parasites also target specific cell lineages during embryogenesis (Dunn et al. 1998, Weedall et al. 2006). Only merogonic (vegetative) stages of the parasite have been observed in embryos (Terry et al. 
1997) and so targeting of host tissues is not a result of parasite spore germination. However, the localization of parasites within the perinuclear zone and their close association of parasite meronts with host microtubules suggest that they segregate with the spindle microtubules at host cell mitosis (Terry et al. 1999b). This is likely to benefit both parasite and host, as the exclusion of the parasite from the spindle zone will ensure that nuclear division is not disrupted. [Fig. 14.5 near here]

In contrast with feminizing Microsporidia in amphipods, Wolbachia bacteria do not target reproductive tissues of woodlice during embryogenesis (Sicard et al. 2014). Although bacteria show the highest multiplication rate in ovarian tissue (Fast et al. 2011), they also colonize tissues as diverse as fat bodies, gut epithelium, nerve chord, brain, and haemocytes (Dittmer et al. 2014). It is possible that bacterial colonization of somatic tissues contributes to some potential for horizontal transmission (Sicard et al. 2014). Furthermore, in the isopod $A$. vulgare, the higher multiplication rate of Wolbachia in the germ line is not anarchic and massive. It is also fine-tuned, as observed for Microsporidia in gammarid amphipods. A progressive enrichment of Wolbachia-infected oocytes in the course of ovary maturation is observed (Fig. 14.6), suggesting either a secondary colonization of previously uninfected oocytes or the preferential development of infected ones (Genty et al., 2014).

The precise molecular mechanism(s) of parasite-induced feminization are not known, but it appears that parallel mechanisms of feminisation may be employed by the phylogentically distinct feminizers that infect the amphipod G. duebeni (parasitic fungi of the phylum Microsporidia) and the terrestrial isopod A. vulgare (bacteria of the genus Wolbachia). It appears that these parasites act by manipulating the hormonal control of sex differentiation of the host. In crustaceans, male sexual differentiation is controlled by the extragonadal hormone androgenic gland hormone (AGH) that is secreted by the androgenic gland located at the distal end of the vas deferens (Charniaux-Cotton and Payen 1985, 
Cerveau et al. 2014). In the absence of androgenic gland differentiation, female development occurs (Katakura 1989). Rodgers-Gray et al. (2004) found that N. granulosis infected (feminized) G. duebeni had fully developed ovaries and an undifferentiated androgenic gland, identical to that found in true (uninfected) females. Furthermore, while AGH was produced by males, it was absent from uninfected females and infected, feminized individuals, suggesting that $N$. granulosis manipulates host sex by preventing androgenic gland differentiation and AGH production and, consequently, male differentiation. Similarly, Wolbachia appears to prevent androgenic gland differentiation during sexual differentiation of A. vulgare (reviewed in Rigaud et al. 1997). The cue for sex determination and differentiation in A. vulgare appears to be the "male" gene(s), which controls the development of the androgenic gland. Wolbachia could therefore target these "male" gene(s) resulting in an absence of the development of the androgenic gland, leading to female sex differentiation. It is interesting to note that such diverse parasite taxa (Microsporidia and Wolbachia) show convergent evolution, each leading to sex ratio distortion by manipulation sex differentiation in their crustacean hosts. [Fig. 14.6 near here]

<3> Ecological Impacts: Sex Ratio Distorters and Biological Invasions Invasive species are a major driver of biodiversity loss globally and understanding what makes a successful invader is key to predicting and managing invasions. Successful invaders tend to be larger, more fecund and more abundant in invaded areas compared to their original ranges (Parker et al. 2013). One hypothesis to explain the success of these invasive species is that they benefit from escaping their natural enemies: for example, analysis of data from 26 invasive species including mammals, reptiles, amphibians, birds, fish, mollusks, and crustaceans revealed lower parasite diversity in the invasive than in the native range for the majority of species (Torchin et al. 2003). Loss of parasites may be driven by sampling effects 
(infected individuals may be absent in introduced propagules) and by selective effects (infected individuals may be less fit, and initial host density during the colonization phase may be insufficient to sustain a parasite population; Torchin et al. 2003, Colautti et al. 2004).

However, vertically transmitted parasites do not experience the same selective pressures as their transmission is not dependent on parasite burden, and they typically cause little virulence (Bandi et al. 2001, Dunn and Smith 2001). Hence, they are less likely to be lost during the invasion process (Mitchell and Power 2003, Galbreath et al. 2004). Evidence from plant pathogens supports this prediction; invasive plants were more likely to show release from fungi than from viruses that are often seed-transmitted (Mitchell and Power 2003), although evidence from animal pathogens is more equivocal (reviewed in Hatcher and Dunn 2011). Vertically transmitted sex ratio distorters have in fact been predicted to enhance invasion success as they may increase population growth through over-production of females (Slothouber Galbreath et al. 2010). For example, although invasive populations of the amphipod Crangonyx pseudogracilis have undergone a genetic bottleneck, Slothouber Galbreath et al. (2010) found no evidence for enemy release, but found that two vertically transmitted parasites had been co-introduced. One of these, the microsporidian feminizer Fibrillanosema crangonycis, was prevalent in all populations, suggesting that the production of excess females facilitated amphipod population growth (Slothouber Galbreath et al. 2010). Similarly, a study of the invasive amphipod Dikerogammarus villosus in Europe found no evidence of either a genetic bottleneck or of enemy release. However, this invader had acquired two microsporidian parasites within its invasive range that are related to the feminizer N. granulosis and which may therefore facilitate the ongoing D. villosus invasion (Wattier et al. 2007).

$<3>$ Parasitism and Crustacean Reproductive Behavior 
In addition to directly disrupting sex determination and differentiation, parasitism can affect behavioral traits with diverse consequences including determining mating success, affecting patterns of assortative pairing, altering mate choice, and changing investment of resources to sperm.

Parasites with an indirect life cycle can induce dramatic changes in the anti-predator behavior of their hosts, thereby increasing trophic transmission to the parasite's final hosts (Hughes et al. 2012). These behavioral changes may also disrupt patterns of assortative pairing. For example, the trematode Microphallus papillorobustus causes its amphipod host, Gammarus insensibilis, to move to the surface of the water column, thereby increasing the likelihood of predation by the definitive bird host. This change in micro-habitat selection also increases the encounter rate with other infected individuals thus generating assortative pairing by parasite prevalence (Thomas et al. 1996). In contrast, Gammarus pulex infected by the acanthocephalans Pomphorhynchus laevis and Polymorphus minutus show a decreased probability of pairing (Bollache et al. 2001, 2002). This is unlikely to benefit the parasite as predation by fish (the definitive hosts for these parasites) may be higher on paired than single amphipods (Cothran 2004). However, it may reflect parasite manipulation of host, diverting energy allocation from mating behaviors to traits that increase transmission (i.e., behavioral manipulation). This hypothesis has not yet been tested.

Fecundity compensation is an adaptive host response that reduces the lifetime fitness cost of parasitic infection by increasing reproductive effort in the initial stages of infection (see above "Evolutionary Significance of Parasitic Castration"). For example, the trematode Gynaecotyla adunca manipulates the antipredator behavior of its amphipod host Corophium volutator. Once the trematode develops to the infective stage, it makes the host crawl on the surface of a mudflat where it is vulnerable to predation by the final host (sandpipers, Calidris pusilla). Interestingly, male Corophium compensate for future parasite-induced predation by 
showing increased mating and ejaculate size in the period post-infection but before parasite manipulation occurs (McCurdy et al. 2001).

<3> Parasitic Sex Ratio Distortion and Crustacean Reproductive Behavior Owing to the transmission route of sex ratio distorters, selection on the parasite could favor reduced virulence, but also manipulation to increase its own reproductive success, whatever the impact on the host fitness (Bandi et al. 2001). For example, infection by the microsporidian feminizing parasites $N$. granulosis and $D$. duebenum is associated with slightly reduced survival and fecundity in the amphipod host, $G$. duebeni, but feminization compensate this fitness cost, and parasite transmission remains high (Terry et al. 1998, Ironside et al. 2003).

In contrast, selection on the host should favor any behavior that reduces the potential cost of sex ratio distortion. Mating with infected feminized hosts is likely to be disadvantageous as in some systems these hosts suffer reduced fecundity. Furthermore, under female-biased sex ratios (as a result of infection) individuals that invest in sons will have higher fitness (Fisher 1930). In the isopod Armadillidium vulgare males prefer to mate with "real" females relative to Wolbachia-reversed females (Moreau et al. 2001). In the amphipod G. duebeni males invest less time guarding infected than uninfected females (Kelly et al. 2001). In addition, both amphipod and isopod males allocate more sperm to uninfected females (Rigaud and Moreau 2004, Dunn et al. 2006). This could result from strategic sperm allocation (in G. duebeni uninfected females produces more eggs than infected ones), or be a consequence of a lower attractiveness of infected females in A. vulgare (Moreau et al. 2001). This reduction in sperm allocation has negative consequences for female fertility (Rigaud and Moreau 2004, Dunn et al. 2006), which may, in turn, limit the spread of parasitic feminizers in host populations. Parasite-induced sex ratio biases may also underpin between-species 
differences in mating capacity: in isopod species infected by feminizing bacteria, males have evolved an increased ability to inseminate more females (in response to strong female-biased population sex ratios), relative to species infected by closely-related non-feminizing Wolbachia (Moreau and Rigaud 2003).

\section{$<1>$ Intersexuality in Crustacea}

Intersexuality is the abnormal condition whereby gonochoristic individuals display both male and female characteristics. In contrast with hermaphrodite species, intersexuality in gonochoristic species results from abnormal development and intersex individuals suffer a fitness cost in comparison with males or females. Intersexes are widely reported in gonochoristic crustaceans and several mechanisms have been proposed for its occurrence (Ford 2008), including incomplete environmental sex determination (Dunn et al 1996), incomplete parasite-induced feminization (Kelly et al 2004), and the impact of environmental pollutants (Ford 2008; deFur and Williams 2015).

In some instances, intersex characteristics can be observed externally in the form of both male and female appendages (external genitalia and gnathopods), while in others it is only revealed by careful examination of gonadal structures or histology of the testicular or ovarian tissues. Within the literature, some authors have classified intersex specimens into intersex male or intersex female when characteristics of one sex are more predominant. With so many examples of sequential and simultaneous hermaphrodites in crustaceans (Yaldwyn 1966, Baeza et al. 2009; see also Chapter 8, this volume), there has been confusion as to whether accounts of intersexuality in the literature are correct, or whether these specimens simply had a poorly understood life history (Ford 2012).

The first known published accounts of "intersex" in a crustacean was a specimen of "a hermaphrodite lobster" presented in a report to the Royal Society in 1729 (Nicholls 1730), 
that described a specimen which was male on one side and female on the other. Ford (2012) highlighted that this was more likely an example of bilateral gynandromorphism and not hermaphroditism, which has since been reported in many crustaceans. Subsequently, many cases of gynandromorphy have been reported in lobsters (Chase and Moore 1859) and other crustaceans across many classes (Bowen 1962, Farmer 1972, Johnson and Otto 1981, Taylor 1986, Micheli 1991, Olmstead and Leblanc 2007).

Bilateral gynandromorphism is a condition which is thought to arise when genes (e.g., governing sex determination) are altered during the bilateral developmental of an embryo, resulting in one side appearing male and the other female (Levin and Palmer 2007). Mosaic gynandromorphism can also occur whereby individuals demonstrate a more patterned (mosaic) formation of phenotypic characters (e.g., coloration) and is best understood in the insects (Michez et al. 2009). In most cases, such gynandromorphs are thought to arise early in embryonic development during midplane formation (Wolff and Scholtz 2002, Levin and Palmer 2007). Under the current definitions, gynandromorphs might be considered a form of intersexuality in that they are abnormal and occur in gonochoristic species. As opposed to sexual gynandromorphs, which might be considered to have more of a developmental underpinning, the causes of intersexuality are multifaceted and may occur due to disturbances in sex determination or sexual differentiation.

Intersexuality is certainly not a new phenomenon. An intersex fossil crab has been reported from the upper Cretaceous dating back about 70 million years ago (Bishop 1973). Despite the outlined confusion, intersexuality (including gynandromorphs) has been reported within the literature among a wide variety of taxa including Anostraca (Bowen and Hanson 1961), Decapoda (Yaldwyn 1966), Copepoda (Moore and Stevenson 1991, Gusmão and McKinnon 2009), Mysidacea (Mees et al. 1995), Isopoda (Rigaud and Juchault 1998), Cladocera (Mitchell 2001), Anomura (Turra 2004), and Amphipoda (Ford and Fernandes 
2005a). A considerable body of literature now exists for the incidences and phenotypes of intersexuality in the Amphipoda and Isopoda (Table 14.2). Within both these groups reports exist for both intersex males and intersex females. While at this stage the causal factors are unclear, Ford and Fernandes (2005a) speculated that separate sexual phenotypes may be due to environmental and/or parasite-induced disruption around critical periods in sex determination. [Table. 14.2 near here]

\section{<2> Environmental Sex Determination and Intersexuality}

Environmental sex determination (ESD) is an adaptive strategy found in diverse taxa including some amphipod species, which allows individuals to match their sex to their future size-related fitness (see above "Environmental Sex Determination in the Amphipoda"). Crustacea develop as male when the androgenic gland differentiates and produces androgenic gland hormone, or become female in the absence of androgenic gland differentiation and it has been proposed that, in amphipods with ESD, the environmental cues stimulate androgen gland differentiation. There is evidence that intersexes can result from incomplete sexual differentiation under ESD. Higher intersex frequency has been reported in G. duebeni populations where the level of ESD is high, and intersexes were found to be more common in months when environmental cues lead to male-biased sex ratios. Similarly, amphipods reared in the lab under conditions that cue males were more likely to show intersex characteristics than those raised under female-determining conditions, suggesting that one cause of intersexuality was incomplete androgenic gland differentiation and hence male sexual differentiation under ESD (Dunn et al. 1993, Dunn et al. 1996). Hence the risk of intersexuality may be due to the cost of the delayed and flexible sexual differentiation that is a hallmark of ESD. 
$<2>$ Parasite Induced Intersexuality

Intersexuality can also result from incomplete feminization by sex ratio distorting parasites (Kelly et al. 2004). Rodgers-Gray et al. (2004) found that $97 \%$ of intersex G. duebeni amphipods from a population from Northumberland, UK were infected by the microsporidian feminiser N. granulosis (prevalence in females was only 38\%). These intersexes showed both male and female external sexual characteristics. Their gonads included an ovary and oviduct and a vestigial androgenic gland, identical to the morphology of females, but a vestigial vas deferens was also present (Fig. 14.7). Males have also been shown to prefer mating with females than with intersex females, and intersex females also had reduced fecundity (Kelly et al. 2004). Therefore, intersexuality is likely to be disadvantageous to both the host and the parasite which relies on host reproduction for transmission to future host generations. [Fig.

\section{7 near here]}

Intersexes are also found, sometimes at high numbers, in populations of the terrestrial isopod Armadillidium vulgare (Juchault et al. 1992). Two kinds of intersexes are found, with contrasting functional phenotypes. First, some individuals show functional male gonads (and mating behavior), but non-functional, tiny vas deferens that open on the female genital apertures. These intersexes function as males and result from the conflict between the feminizing " $\mathrm{f}$ " sex factor (probably from bacterial origin) and an autosomal gene restoring the

male sex. Here, the intersex phenotype (with female gonopores) is a trace of an incomplete restoration of the male sex (Rigaud and Juchault 1993). Other intersex phenotypes in this species are variable, with all intermediate stages between fertile females with gonads showing non-functional vas deferens and male genital papillae (intersex females, $\mathrm{iF}$ ) to sterile individuals with gonads showing characteristics of non-functional testes with hypertrophied androgenic glands (intersex males, iM). These phenotypes are the expression of delayed feminization induced by Wolbachia (Rigaud and Juchault 1993). Longer delays increase the 
probability of a sterile iM phenotype. Delayed feminization can be induced by an autosomal repressor of feminization or by the detrimental effect of high temperature on the multiplication of Wolbachia bacteria (Rigaud and Juchault 1993, 1998). Such dysfunction of parasite-induced feminization therefore leads to high proportions of sterile intersexes, which is disadvantageous for the population growth of both the woodlouse host and bacteria.

\section{$<2>$ Pollution and Sex Determination}

Since the early 1990s there have been concerns that pollutants termed endocrine-disrupting chemicals (EDCs) have the capacity to cause reproductive abnormalities in wildlife (Colborn et al. 1996, Norris and Carr 2005, deFur and Williams 2015). Many of these reproductive abnormalities were reported in vertebrates including fish (Jobling et al. 1998), reptiles (Crain and Guillette 1998), and amphibians (Hayes et al. 2002). Several of these reproductive aberrations manifest themselves as an intersex condition in which organisms "abnormally" display characteristics of both males and females (as opposed to sequential hermaphrodites in transition between sexes or simultaneous hermaphrodites). The chemicals involved vary from natural and synthetically produced estrogens to industrial contaminants such as pesticides, hydrocarbons and polychlorinated biphenyls (PCBs). Towards the very end of the 20th century, there was more emphasis on the potential impacts of EDCs on invertebrates (Oetken et al. 2004). Until this time, the only well documented case of endocrine disruption was “imposex" in gastropod molluscs caused by tributyltin (TBT)-based paints (Bryan et al 1986). Imposex referred to the imposition of one sex genitalia on another. In this instance, the female gastropods developed a penis and vas deferens, blocking the oviducts and causing sterility. Sometimes the term 'imposex' has been wrongly used in crustaceans and might have been more appropriately called intersexuality (e.g., Takahashi et al. 2000). 
As a result of the focus on pollution potentially impacting sex determination and differentiation, the number of published incidences of intersexuality in invertebrates, including crustaceans, began to rise (Ford 2012). A number of studies have highlighted correlations between pollution and intersexuality in Crustacea (Moore and Stevenson 1991, 1994, Takahashi et al. 2000, Barbeau and Grecian 2003, Vandenbergh et al. 2003, Jungmann et al. 2004, Ford et al. 2004, Ayaki et al. 2005). While there has been speculation that individual cases of bilateral gynandromorphs might have been caused by pollutants disrupting sexual development, this has not been substantiated from thorough field and laboratory studies. Research from the field has mainly focused on intersex individuals that display an array of external or internal male and female characteristics as a result of feminization/defeminization or masculization/demasculinization. For example, Moore and Stevenson $(1991,1994)$ reported an elevated number of intersex copepods around sewage effluent discharge although a follow-up study found no correlation between intersexuality and distance from the pollution discharge (Moore and Stevenson 1994). Takahashi et al. (2000) found high prevalence (34-63\% males with gonopores and 12-28\% females with penis-like appendages) of intersex freshwater crabs in contaminated compared to none in "clean" Japanese rivers. However, although a large number of possible pollutants were measured, none were correlated with the observed intersexuality nor were parasites implicated as a causal factor. Ayaki et al. (2005) similarly found high numbers of intersexuality (8-32\%) in male crabs from Japanese freshwater streams but could not identify a causal factor, speculating that chemicals from agricultural runoff were the cause. Jungmann et al. (2004) found that, when amphipods (Gammarus fossarum) collected from streams with a low prevalence of intersexuality were caged in streams with high levels of intersex, or kept under laboratory conditions in water from high-intersex streams, a greater proportion became 
intersexed than if kept in "low-intersex" stream water. However, the role of parasites could not be ruled out nor was any specific chemical contaminant identified.

The only laboratory-confirmed cases of intersexuality caused by chemical contamination are studies conducted on Daphnia following exposure to a pesticide. Olmstead and LeBlanc (2002) found that the terpenoid hormone methyl farnesoate (MF) is a sexdetermining factor in Daphnia and that elevated concentrations of MF or MF synthetic analogues resulted in all-male broods. The same authors also demonstrated that exposing Daphnia to MF in the laboratory can induce sexual gynandromorphism (Olmstead and LeBlanc 2007). Methyl farnesoate is structurally similar to juvenile hormones (III) in insects and these researchers also found that increased temperature synergized with pesticides based on juvenile hormone analogues cause elevated numbers of intersex progeny. Therefore, it is conceivable, based on laboratory studies, that man-made pesticides could disrupt sexual development in crustaceans. In a study exposing amphipods to $17 \alpha$-ethinylestradiol, Vandenbergh et al. (2003) found that first generation males had smaller gnathopods, intersex testes and disrupted spermatogenesis, although the potential role of parasites in the observed results was unclear (Ford and Fernandes 2005b).

Pollution might increase the prevalence of feminizing parasites in crustaceans, thus causing a form of "indirect" endocrine disruption (Ford et al. 2006). High numbers of intersex amphipods (Echinogammarus marinus: $30 \%$ ) were recorded around industrially polluted bays in Scotland while relatively low numbers $(\sim 3-5 \%)$ were recorded at reference locations (Ford et al. 2004). The intersexuality correlated strongly with microsporidian infections that were identified using histological methods (Ford et al. 2006) and later confirmed to be the feminizing microsporidium Dictyocoela duebenum. Yang et al. $(2008,2011)$ highlighted another phenotype of intersexuality in the amphipod E. marinus in which ovotestes were observed internally in males but no external feminized features were observed. These 
internally intersexed specimens were not associated with any known feminizing parasites (Short et al. 2012), thus opening the possibility of pollution and parasite-induced intersexuality. Using high throughput sequencing technologies to compare the transcriptomes, the parasite infected external intersex and the uninfected internal intersex specimens had broadly similar gene expression (Short et al., 2012, 2014). Interestingly, Short et al. (2014) reported that despite a substantial up-regulation of female-related genes in intersex male amphipods, there was no concomitant decrease in male-related genes as demonstrated in vertebrate species. Conversely, $\mathrm{Li}$ (2002) found that intersexuality in Taiwanese crabs (Grapsus albolineatus) decreased with contamination with $80 \%$ intersexuality observed at reference sites and only $30 \%$ intersexuality close to a municipal landfill. In this instance the intersexuality referred to was feminization of appendages (claws and abdomens) caused by rhizocephalan parasites and it was speculated that the parasite larvae might be susceptible to poor water quality.

Therefore, to date, despite a large number of studies highlighting intersexuality within the Crustacea, few have demonstrated that intersexuality can be induced experimentally through exposure to pollutants or linked intersex phenotypes to pollution in the field. With the relative plasticity of sex determination found throughout crustaceans, it seems possible that some compounds could interfere with the process of sex determination or differentiation. With the advent of affordable genomic and transcriptomic sequencing the ability to search for sex-determining genes and those involved in downstream sexual differentiation is now possible in non-model organisms. This is rapidly expanding our knowledge of crustacean developmental biology and should enable us to gain a better understanding of the impacts of pollution on sex-determining mechanisms.

$<1>$ Conclusions 
Crustacea show a wide range of environmental effects on their reproduction. These range from the evolutionary adaptive environmental sex determination, through manipulation of individual sex determination and population sex ratio by parasites and pollutants, to catastrophic parasite-induced castration. The examples reviewed here reveal a high degree of plasticity in sex determination, reproduction, and behavior. It appears that the neuroendocrine control of sex determination in Crustacea is key to this plasticity. On the one hand, this sex determination system underlies the evolution of adaptive sex determination in response to environmental factors such as sex-specific fitness (ESD) or sex ratio biases. However, it may also explain the vulnerability of these organisms to manipulation by parasites and altered development due to pollutants.

The conflict between crustacean hosts and their reproductive parasites provides some elegant examples of co-evolution in action, and studies to date suggest that such phenomena may be widespread among crustaceans. Future studies of these fascinating interactions should explore the mechanism of action. Parasites infecting crustaceans come from divergent taxa, prokaryotes (Bacteria) feminize isopods and eukaryotes (Microsporidia) feminize amphipods; are the mechanisms responsible for feminization the same, reflecting the vulnerability of crustacean sex determination to manipulation, or are there contrasting mechanisms leading to evolutionary convergence? Another interesting question to explore would be the evolution of sex ratio manipulation: are the dynamics of sex ratio evolution the same among crustacean/parasite pairs? For a given host species what is the diversity of feminizing parasites, and, more broadly, are there different degrees of specificity among host/parasite species? Data exist for some models (WolbachialArmadillidium vulgare and microsporidia/Gammarus duebeni) but other parasite/host couples remained too overlooked to build a general picture. 
Anthropogenic factors including pollution are also likely to impose increasing pressures on Crustacea. Crustacea play keystone roles in aquatic communities, hence the impact of pollutants on reproductive development and thus, crustacean population dynamics could have profound ramifications for energy flow and the structure of aquatic communities. Laboratory evidence suggests it is conceivable that pollutants can impact sexual differentiation/development in crustaceans, with field-based studies highlighting correlations between contamination and intersexuality. Future studies need to address the interaction between ESD, and environmental contamination on crustacean reproduction and development. This will require a better fundamental knowledge of the mechanisms of sex determination and differentiation. The advent of affordable sequencing technologies now make these fundamental research questions achievable, which will ultimately benefit giving adequate responses to the applied questions related to environmental quality, fisheries and climate change.

\section{$<1>$ References}

Adams, J., P. Greenwood, and C. Naylor. 1987. Evolutionary aspects of environmental sex determination. International Journal of Invertebrate Reproduction and Development $11: 123-135$.

Anders, F. 1957. Uber die geschlechtsbeeinflussende Wirkung von Farballelen bei Gammarus pulex ssp. Subterraneus. Zeitschrift fuer induktive Abstammungs und Vererbungslehre 88: 291-332.

Anderson, R.M., and R.M. May. 1979. Population biology of infectious diseases. 1. Nature 280:361-367. 
Ayaki, T., Y. Kawauchino, C. Nishimura, H. Ishibashi, and K. Arizono 2005. Sexual disruption in the freshwater crab (Geothelphusa dehaani). Integrative and Comparative Biology 45:39-42.

Baeza, J.A., C.D. Schubart, P. Zillner, S. Fuentes, and R.T. Bauer. 2009. Molecular phylogeny of shrimps from the genus Lysmata (Caridea: Hippolytidae): the evolutionary origins of protandric simultaneous hermaphroditism and social monogamy. Biological Journal of the Linnean Society 96:415-424.

Bandi, C., A.M. Dunn, G.D.D. Hurst, and T. Rigaud. 2001. Inherited microorganisms, sexspecific virulence and reproductive parasitism. Trends in Parasitology 17:88-94.

Barbeau, M.A., and L.A. Grecian. 2003. Occurrence of intersexuality in the amphipod Corophium volutator (Pallas) in the upper bay of Fundy, Canada. Crustaceana 76:665679.

Baudoin, M. 1975. Host castration as a parasitic strategy. Evolution 29:335-352.

Becheikh, S., Michaud, M., Thomas, F., Raibaut, A., and Renaud, F. 1998. Roles of resource and partner availability in sex determination in a parasitic copepod. Proceedings of the Royal Society B-Biological Sciences 265:1153-1156

Bellon-Humbert, C. 1983. Eecampia erythrocephala Giard (Turbellaria Neorhabdocoela), a parasite of the prawn Palaemon serratus pennant: the adult phase. Aquaculture 31:117140.

Bishop, G. A. 1973. A sexually aberrant crab (Dakoticancer overanus Rathbun, 1917) from the upper cretaceous pierre shale of South Dakota. Crustaceana. 26:212-218.

Bollache, L., G. Gambade, and F. Cezilly. 2001. The effects of two acanthocephalan parasites, Pomphorhynchus laevis and Polymorphus minutus, on pairing success in male Gammarus pulex (Crustacea: Amphipoda). Behavioural Ecology and Sociobiology 49:296-303. 
Bollache, L., T. Rigaud, and F. Cezilly. 2002. Effects of two acanthocephalan parasites on the fecundity and pairing status of female Gammarus pulex (Crustacea: Amphipoda). Journal of Invertebrate Pathology 79: 102-110.

Bonds, M.H. 2006. Host life-history strategy explains pathogen-induced sterility. American Naturalist 168:281-293.

Bouchon, D., T. Rigaud, and P. Juchault. 1998. Evidence for widespread Wolbachia infection in isopod crustaceans: molecular identification and host feminization. Proceedings of the Royal Society of London Series B 265:1081-1090.

Bowen, S.T., and J. Hanson. 1962. Gynandromorph of brine shrimp, Artemia salina. Genetics $47: 227-230$.

Brattey, J. 1983. The effects of larval Acanthocephalus lucii on the pigmentation, reproduction and susceptibility to predation of the isopod Asellus aquaticus. Journal of Parasitology 69:1172-1173.

Bryan, G.W., P.E. Gibbs, L.G. Hummerstone, and G.R. Burt 1986. The decline of the gastropod Nucella lapillus around south-west England: evidence for the effect of tributyltin from antifouling paints. Journal of the Marine Biological Association of the United Kingdom 66:611-640.

Buikema, A. L., A.L. Chester, and H.R. Stevens. 1980. Intersexuality in Gammarus minus. Say Crustaceana 6:111-117.

Bulnheim, H.P. 1965. Untersuchungen uber intersexualitat bei Gammarus duebeni (Crustacea, Amphipoda). Helgolander Wissenschaftliche Meeresuntersuchungen 12:349-394.

Bulnheim, H.P. 1978. Interaction between genetic, external and parasitic factors in sex determination of crustacean amphipod Gammarus duebeni. Helgolander Wissenschaftliche Meeresuntersuchungen 31:1-33. 
Bulnheim, H.P., and J. Vavra. 1968. Infection by microsporidian Octosporea effeminans sp n and its sex determining influence in amphipod Gammarus duebeni. Journal of Parasitology 54:241-\&.

Calado, R., A. Vitorino, and M.T. Dinis 2006. Bopyrid isopods do not castrate the simultaneously hermaphroditic shrimp Lysmata amboinensis (Decapoda: Hippolytidae). Diseases of Aquatic Organisms 73:73-76.

Calado, R., C. Bartilotti, and L. Narciso. 2005. Short report on the effect of a parasitic isopod on the reproductive performance of a shrimp. Journal of Experimental Marine Biology and Ecology 321:13-18.

Caubet, Y., M.J. Hatcher, J.P. Mocquard, and T. Rigaud. 2000. Genetic conflict and changes in heterogametic mechanisms of sex determination. Journal of Evolutionary Biology 13:766-777.

Cerveau, N., D. Bouchon, T. Berges, and P. Greve. 2014. Molecular evolution of the androgenic hormone in terrestrial isopods. Gene 540:71-77.

Charniaux-Cotton, H., and G. Payen. 1985. Sexual differentiation. Pages 217-299 in D. E. Bliss and L. H. Mantel, editors. The Biology of Crustacea. Vol. 9: Integument, Pigments, and Hormonal Processes. Academic Press, New York, USA.

Charnov, E.L., and J. Bull. 1977. When is sex environmentally determined? Nature (London) 266:828-830.

Chase, F.A., and G.M. Moore. 1959. A bicolored gynandromorph of the lobster, Homarus americanus. Biological Bulletin 116:226-231.

Colautti, R.I., A. Ricciardi, I.A. Grigorovich, and H.J. MacIsaac. 2004. Is invasion success explained by the enemy release hypothesis? Ecology Letters 7:721-733.

Colborn, T., M.J. Peterson, and D. Dumanoski 1996. Our Stolen Future. Little Brown and Co., Boston, Page 306. 
Conover, D.O. 1984. Adaptive significance of temperature-dependent sex determination in a fish. American Naturalist 123:297-313.

Cordaux, R, A. Michel-Salzat, and D. Bouchon. 2001. Wolbachia infection in crustaceans: novel hosts and potential routes for horizontal transmission. Journal of Evolutionary Biology 14:237-243.

Cordaux, R., A. Michel-Salzat, M. Frelon-Raimond, T. Rigaud, and D. Bouchon. 2004. Evidence for a new feminizing Wolbachia strain in the isopod Armadillidium vulgare: evolutionary implications. Heredity 93:78-84.

Cordaux, R., D. Bouchon, and P. Grève. 2011. The impact of endosymbionts on the evolution of host sex-determination mechanisms. Trends in Genetics 27:332-341.

Cordaux, R., S. Pichon, H.B. Hatira, V. Doublet, P. Greve, I. Marcade, C. Braquart-Varnier, C. Souty-Grosset, F. Charfi-Cheilchrouha, and D. Bouchon. 2012. Widespread Wolbachia infection in terrestrial isopods and other crustaceans. Zookeys 176:123-131.

Cothran, R.D. 2004. Precopulatory mate guarding affects predation risk in two freshwater amphipod species. Animal Behaviour, 68:1133-1138.

Crain, D. A., and L.J. Guillette. 1998. Reptiles as models of contaminant-induced endocrine disruption. Animal reproduction Science 53:77-86.

Dalens, H., 1968 Intersexuality in species Chaetophiloscia elongata (dollfus) (Isopoda Oniscoidea Oniscidae). Comptes Rendus Hebdomadaires des Seances de l'Academie des Sciences Serie D 267:1212-\&.

Decaestecker, E., S. Declerck, L. de Meester, and D. Ebert. 2005. Ecological implications of parasites in natural Daphnia populations. Oecologia 144:382-390.

deFur, P.L., and L.E. Williams. 2015. Endocrine-disrupting chemicals. Pages 461-476 in E, Chang and M. Thiel, editors. The Natural History of the Crustacea, vol. 4: Physiology. Oxford Press, New York, USA. 
Dittmer, J., S. Beltran-Bech, J. Lesobre, M. Raimond, M. Johnson, and D. Bouchon. 2014. Host tissues as microhabitats for Wolbachia and quantitative insights into the bacterial community in terrestrial isopods. Molecular Ecology 23:2619-2635.

Dobson, A.P., and M. Crawley. 1994. Pathogens and the structure of plant communities. Trends in Ecology and Evolution 9:393-398.

Dubuffet, A., J.E. Smith, L. Solter, M.A. Perotti, H.R. Braig, and A.M. Dunn. 2013. Specific detection and localization of microsporidian parasites in invertebrate hosts by using in situ hybridization. Applied and Environmental Microbiology 79:385-388.

Duffy, T.A., L.A. Hice, and D.O. Conover. 2015. Pattern and scale of geographic variation in environmental sex determination in the Atlantic silverside, Menidia menidia. Evolution 69:2187-2195.

Dumbauld, B.R., J.W. Chapman, M.E. Torchin, and A.M. Kuris. 2011. Is the collapse of mud shrimp (Upogebia pugettensis) populations along the pacific coast of North America caused by outbreaks of a previously unknown bopyrid isopod parasite (Orthione griffenis)? Estuaries and Coasts 34:336-350.

Duneau D., P. Luijckx, L.F. Ruder and D. Ebert. 2012. Sex-specific effects of a parasite evolving in a female-biased host population. BMC Biology 10:104.

Dunn, A.M. 2009. Parasites and biological invasions. Advances in Parasitology 68:161-84.

Dunn, A.M., T. Andrews, H. Ingrey, J. Riley, and N. Wedell. 2006. Strategic sperm allocation under parasitic sex ratio distortion. Biology Letters 2:78-80.

Dunn, A.M., and J.E. Smith. 2001. Microsporidian life cycles and diversity: the relationship between virulence and transmission. Microbes and Infection 3:381-388.

Dunn, A. M., J. Adams, and J.E. Smith. 1990. Intersexes in a shrimp: a possible disadvantage of environmental sex determination. Evolution 44:1875-1878. 
Dunn, A.M., J. Adams, and J.E. Smith. 1993. Is intersexuality a cost of environmental sex determination in Gammarus duebeni? Journal of Zoology 231:383-389.

Dunn, A.M., J. McCabe, and J. Adams. 1996. Intersexuality in Gammarus duebenii (Amphipoda), a cost incurred in populations with environmental sex determination? Crustaceana 69:313-320.

Dunn, A.M., J.C. Hogg, A. Kelly, and M.J. Hatcher. 2005. Two cues for sex determination in Gammarus duebeni: Adaptive variation in environmental sex determination? Limnology and Oceanography 50:346-353.

Dunn, A.M., R.S. Terry, and D.E. Taneyhill. 1998. Within-host transmission strategies of transovarial, feminizing parasites of Gammarus duebeni. Parasitology 117:21-30.

Ebert, D., H.J. Carius, T. Little, and E. Decaestecker. 2004. The evolution of virulence when parasites cause host castration and gigantism. American Naturalist 164:S19-S32.

Farmer, A.S. 1972. A bilateral gynandromorph of Nephrops norvegicus (Decapoda: Nephrophidae). Crustaceana 27:17-20.

Fast E.M., M.E. Toomey, K. Panaram, D. Desjardins, E.D. Kolaczyk, and H.M. Frydman. 2011. Wolbachia enhance Drosophila stem cell proliferation and target the germline stem cell niche. Science 334:990-992.

Ferreira, S.M., K.T. Jensen, P.A. Martins, S.F. Sousa, J.C. Marques, and M.A. Pardal. 2005. Impact of microphallid trematodes on the survivorship, growth, and reproduction of an isopod (Cyathura carinata). Journal of Experimental Marine Biology and Ecology 318:191-199.

Fisher R.A. 1930. The Genetical Theory of Natural Selection. Clarendon Press, Oxford Ford, A.T. 2012. Intersexuality in Crustacea: an environmental issue? Aquatic Toxicology 108:125-129.

Ford, A.T. 2008. Can you feminise a crustacean? Aquatic Toxicology 88:316-321. 
Ford, A.T., and T.F. Fernandes. 2005a. Notes on the occurrence of intersex in amphipods. Hydrobiologia 548:313-318.

Ford, A.T., and T.F. Fernandes. 2005b. Better the devil you know? A precautionary approach to using amphipods and daphniids in endocrine disruptor studies. Environmental Toxicology and Chemistry 24:1019-1021.

Ford, A.T., T.F. Fernandes, S.A. Rider, P.A. Read, C.D. Robinson, and I.M. Davies. 2003. Reproduction in the amphipod, Echinogammarus marinus: a comparison between normal and intersex specimens. Journal of the Marine Biological Association of the UK 83:937-940.

Ford, A.T., T.F. Fernandes, S.A. Rider, P.A. Read, C.D. Robinson, and I.M. Davies. 2004. Endocrine disruption in a marine amphipod? Field observations of intersexuality and de-masculinisation. Marine Environmental Research 58:169-173.

Ford, A.T., T.F. Fernandes, P.A. Read, C.D. Robinson, and I.M. Davies 2006. Can pollution cause intersexuality in the amphipod, Echinogammarus marinus? Marine Pollution Bulletin 53:100-106.

Gaillard, M., C. Juillet, F. Cézilly, and M.J. Perrot-Minnot. 2004. Carotenoids of two freshwater amphipod species (Gammarus pulex and G. roeseli) and their common acanthocephalan parasite Polymorphus minutus. Comparative Biochemistry Physiology B 139:129-136.

Galbreath, J., J.E. Smith, R.S. Terry, J.J. Becnel, and A.M. Dunn. 2004. Invasion success of Fibrillanosema crangonycis, n.sp., n.g.: a novel vertically transmitted microsporidian parasite from the invasive amphipod host Crangonyx pseudogracilis. International Journal for Parasitology 34:235-244. 
Galipaud, M., Z. Gauthey, and L. Bollache. 2011. Pairing success and sperm reserve of male Gammarus pulex infected by Cyathocephalus truncatus (Cestoda: Spathebothriidea). Parasitology 138:1429-1435.

Genty, L-M., D. Bouchon, M. Raimond, and J. Bertaux. 2014. Wolbachia infect ovaries in the course of their maturation: last minute passengers and priority travellers? PLOS ONE 9(4):e94577.

Ginsburger-Vogel, T., 1975. Temperature-sensitive intersexuality and its determinism in Orchestia gammarella Pallas. Pages 106-120 in Reinboth, E., editor. Intersexuality in the Animal Kingdom. Springer-Verlag, Berlin, Germany.

Ginsburger-Vogel, T. 1991. Intersexuality in Orchestia mediterranea Costa, 1853, and Orchestia aestuarensis Wildish, 1987 (Amphipoda) - a consequence of hybridization or parasitic infestation. Journal of Crustacean Biology 11:530-539.

Gopalakrishnan, A., M. Rajkumar, S. Ravichandran, J.P. Trilles, and T.M. Vasanthan. 2009. Identification of Parapenaeopsis stylifera, a new host for Epipenaeon ingens. Journal of Environmental Biology 30:1063-1064.

Grafen, A., and M. Ridley. 1983. A model of mate guarding. Journal of Theoretical Biology 102:549-567.

Green Etxabe, A., S. Short, T. Flood, T. Johns, and A.T. Ford. 2015. Pronounced and prevalent intersexuality does not impede the 'Demon Shrimp' invasion. PeerJ, 3, p.e757.

Guler, Y., S. Short, P. Kile, and A.T. Ford. 2012. Integrating field and laboratory evidence for environmental sex determination in the amphipod, Echinogammarus marinus. Marine Biology 159:2885-2890.

Gusmão, L.F.M., and A.D. McKinnon. 2009. Sex ratios, intersexuality and sex change in copepods. Journal of Plankton Research 31:1101-1117. 
Haine, E.R., E. Brondani, K.D. Hume, M.J. Perrot-Minnot, M. Gaillard, and T. Rigaud. 2004. Coexistence of three microsporidia parasites in populations of the freshwater amphipod Gammarus roeseli: evidence for vertical transmission and positive effect on reproduction. International Journal for Parasitology 34:1137-1146.

Haine, E.R., S. Motreuil, and T. Rigaud. 2007. Infection by a vertically-transmitted microsporidian parasite is associated with a female-biased sex ratio and survival advantage in the amphipod Gammarus roeseli. Parasitology 134:1363-1367.

Hastings, M. H. 1981. Intersex specimens of the amphipod, Ampelisca brevicornis (Costa). Crustaceana 41:199-205.

Hatcher, M.J., and A.M. Dunn. 1997. Size and pairing success in Gammarus duebeni: can females be too big? Animal Behaviour 54:1301-1308.

Hatcher, M.J., and A.M. Dunn. 2011. Parasites in ecological communities from interactions to ecosystems. Cambridge University Press, Cambridge, UK.

Hayes, T. B., A. Collins, M. Lee, M. Mendoza, N. Noriega, A.A. Stuart, and A. Vonk. 2002. Hermaphroditic, demasculinized frogs after exposure to the herbicide atrazine at low ecologically relevant doses. Proceedings of the National Academy of Sciences, 99:5476-5480.

Hoeg, J.T., Yusa, Y., and Dreyer, N. 2016. Sex determination in the androdioecious barnacle Scalpellum scalpellum (Crustacea: Cirripedia). Biological Journal of the Linnean Society 118: 359-368.

Howard, H.W. 1942. The genetics of Armadillidium vulgare Latr II. Studies on the inheritance of monogeny and amphogeny. Journal of Genetics 44:143-159.

Hughes, D.P., J. Bordeur, and F. Thomas F. (Eds) 2012. Host manipulation by parasites. Oxford University Press, Oxford, UK. 
Hurd, H. 2001. Host fecundity reduction: a strategy for damage limitation? Trends in Parasitology 17:363-368.

Hynes, H. B. N., and F. Harper, F. 1972. The life histories of Gammarus lacustris and G. pseudolimnaeus in southern Ontario. Crustaceana 3329-341.

Ironside, J.E., J.E. Smith, M.J. Hatcher, R.G. Sharpe, D. Rollinson, and A.M. Dunn. 2003. Two species of feminizing microsporidian parasite coexist in populations of Gammarus duebeni. Journal of Evolutionary Biology 16:467-473.

Jensen, K.H., T. Little, A. Skorping, and D. Ebert. 2006. Empirical support for optimal virulence in a castrating parasite. Plos Biol 4:e197.

Jobling, S., M. Nolan, C.R. Tyler, G. Brighty, G., and J.P. Sumpter. 1998. Widespread sexual disruption in wild fish. Environmental Science and Technology 32:2498-2506.

Johnson, P.T.J., J.E. Longcore, D.E. Stanton, R.B. Carnegie, J.D. Shields, and E.R. Preu. 2006. Chytrid infections of Daphnia pulicaria: development, ecology, pathology and phylogeny of Polycaryum leave. Freshwater Biology 51:634-648.

Johnson, P.T., and S.V. Otto. 1981. Histology of a bilateral gynandromorphy of the blue crab, Callinectes sapidus Rathbun (Decapoda: Portunidae). Biological Bulletin 161:236-245.

Jokela, J., L. Uotila, and J. Taskinen. 1993. Effect of the castrating trematode parasite Rhipido-cotyle fennica on energy allocation of fresh-water clam Anodonta piscinalis. Functional Ecology 7:332-338.

Juchault, P., and J.P. Mocquard. 1993. Transfer of a parasitic sex factor to the nuclear genome of the host: a hypothesis on the evolution of sex determining mechanisms in the terrestrial isopod Armadillidium vulgare Latr. Journal of Evolutionary Biology 6:511528. 
Juchault, P., C. Louis, G. Martin, G., and G. Noulin. 1991. Masculinization of female isopods (Crustacea) correlated with non-Mendelian inheritance of cytoplasmic viruses. Proceedings of the National Academy of Sciences 88(23):10460-10464.

Juchault, P., T. Rigaud, and J.P. Mocquard. 1992. Evolution of sex-determining mechanisms in a wild population of Armadillidium vulgare Latr. (Crustacea, Isopoda): competition between two feminizing parasitic sex factors. Heredity 69:382-390.

Jungmann, D., V. Ladewig, K.-U. Ludwichowski, P. Petzsch, and R. Nagel. 2004. Intersexuality in Gammarus fossarum (Koch) - a common inducible phenomenon? Archiv fur Hydrobiologie 159:511-529.

Karatayev, A.Y., L.E. Burlakova, D.K. Padilla, S.E. Mastitsky, and S. Olenin. 2009. Invaders are not a random selection of species. Biological Invasions 11:2009.

Katakura, Y. 1989. Endocrine and genetic-control of sex-differentiation in the malacostracan crustacea. Invertebrate Reproduction \& Development 16:177-182.

Kelly, A., M.J. Hatcher, and A.M. Dunn. 2004. Intersexuality in the amphipod Gammarus duebeni results from incomplete feminisation by the vertically transmitted parasitic sex ratio distorter Nosema granulosis. Evolutionary Ecology 18:121-132.

Kelly, A., M.J. Hatcher, L. Evans, and A.M. Dunn. 2001. Mate choice and mate guarding under the influence of a vertically transmitted, parasitic sex ratio distorter. Animal Behaviour 61:763-770.

Korczynski, R.E., 1985. Intersexuality in the arctic isopod Mesidotea (= Saduria) sibirica. Arctic 38:68-69.

Korczynski, R.E., 1988. Additional records on intersexuality in the isopod Mesidotea sibirica (Birula, 1896). Canadian Journal of Zoology, 66(8):1896-1898.

Korpelainen, H. 1990. Sex-ratios and conditions required for environmental sex determination in animals. Biological Reviews of the Cambridge Philosophical Society 65:147-184. 
Kristensen, T., A.I. Nielsen, A.I. Jorgensen, K.N. Mouritsen, H. Glenner, J.T. Christensen, J. Lutzen, and J.T. Hoeg. 2012. The selective advantage of host feminization: a case study

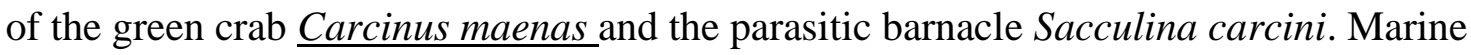
Biology 159:2015-2023.

Kuris, A.M. 1974. Trophic interactions: similarity of parasitic castrators to parasitoids. Quarterly Review of Biology 49:129-148.

Ladewig, V., D. Jungmann, A. Koehler, M. Schirling, R. Triebskorn R., and R. Nagel. 2002. Intersexuality in Gammarus fossarum Koch, 1835 (Amphipoda). Crustaceana 75:12891299.

Lafferty, K.D., and A.M. Kuris. 2009. Parasitic castration: the evolution and ecology of body snatchers. Trends in Parasitology 25:564-572.

Leclercq, S., Thézé, J., Chebbi, M.A., Giraud, I., Moumen, B., Ernenwein, L., Grève,P., Gilbert, C., and Cordaux R. 2016. Birth of a W sex chromosome by horizontal transfer ofWolbachia bacterial symbiont genome. Proceedings of the National Academy of Sciences USA 113:15036-15041.

Levin, M., and A.R. Palmer. 2007 Left-right patterning from the inside out: widespread evidence for intracellular control. Bioessays 29:2271-287.

Li, M.-H., 2002. Fluctuating asymmetry and intersexuality in the shore crab Grapsus albolineatus near coastal landfill site in northern Taiwan. Bulletin of Marine Science 70:75-88.

López Greco, L.S. 2013. Functional anatomy of the reproductive system. Pages 413-450 in L. Watling and M. Thiel, editors. The Natural History of the Crustacea: Functional Morphology and Diversity, Volume 1. Oxford University Press, New York, USA. Maccagno, T. P., and A. Cuniberti. 1956. Intersessualita in Gammarus pungens M. Edw. (Crostacei Anfipodi). Atti della Accademia della Scienze di Torino 90:171-188. 
Martin G., S.G. Gruppe, M. Laulier, D. Bouchon, T. Rigaud, and P. Juchault. 1994. Evidence for Wolbachia spp in the estuarine isopod Sphaeroma rugicauda (Crustacea) - a likely cytoplasmic sex-ratio distorter. Endocytobiosis and Cell Research 10:215-225.

Martin, G., R. Maissiat, P. Juchault, and J.J. Legrand. 1974. Symbiotic introcytoplasmic microorganism in intersexed individuals (males with oostegites) of Crustacea Ligia oceanica-L (Isopoda, Oniscoidea).Comptes Rendus Hebdomadaires Des Seances De L Academie Des Sciences Serie D 278:3375-3378.

McCabe, J., and A.M. Dunn. 1997. Adaptive significance of environmental sex determination in an amphipod. Journal of Evolutionary Biology 10:515-527.

McCurdy, D.G., M.R. Forbes, and J.S. Boates. 1999. Testing alternative hypotheses for variation in amphipod behaviour and life history in relation to parasitism. International Journal for Parasitology 29:1001-1009.

McCurdy, D.G., J.S. Boates, and M.R. Forbes. 2001. An empirical model of the optimal timing of reproduction for female amphipods infected by trematodes. Journal of Parasitology 87:24-30.

McCurdy, D. G., M.R. Forbes, S.P. Logan, M.T. Kopek, and S.I. Mautner. 2004. The functional significance of intersexes in the intertidal amphipod Corophium volutator. Journal of Crustacean Biology 24:261-265.

McDermott, J.J., J.D. Williams, and C.B. Boyko. 2010. The unwanted guests of hermits: a global review of the diversity and natural history of hermit crab parasites. Journal of Experimental Marine Biology and Ecology 394:2-44.

Mees, J., N. Fockedey, A. Dewicke, C.R. Janssen, and J-C. Sorbe 1995. Aberrent individuals of Neomysis integer and other Mysidacea: intersexuality and variable telson morphology. Netherlands Journal of Aquatic Ecology 29:161-166. 
Micheli, F. 1991. Bilateral gynandromorphy of the freshwater crab Potamon fluviatile Herbst (Decapoda: Brachyura). Journal of Crustacean Biology 11:561-568.

Michez, D., P. Rasmont, M. Terzo, M., and N.J. Vereecken. 2009. A synthesis of gynandromorphy among wild bees (Hymenoptera: Apoidea), with an annotated description of several new cases. Pages 365-375 in Annales de la Société Entomologique de France, Vol. 45, No. 3. Taylor \& Francis Group.

Miller, J. D., and A. L. Buikema Jr., 1976. Observations on the ecology of the spring form of Gammarus minus (Form III) Say. Crustaceana 4:153-163.

Mitchell, S.E. 2001. Intersex and male development in Daphnia magna. Hydrobiologia 442:145-156.

Mitchell, C.E., and A.G. Power. 2003. Release of invasive plants from fungal and viral pathogens. Nature 421:625-627.

Mocquard, J.P., E. Legrand-Hamelin, and C. Souty. 1978. Influence of salinity and temperature on fecundity of females and intersexuality of Idotea balthica stagnea Tinturier-Hamelin (Valvifera Isopod). Bulletin de la Société Zoologique de FranceEvolution et Zoologie 103:47-57.

Moore, C.G., and J.M. Stevenson. 1994. Intersexuality in benthic harpacticoid copepods in the firth of forth, Scotland. Journal of Natural History 28:1213-1230.

Moore, C.G., and J.M. Stevenson. 1991. The occurrence of intersexuality in harpacticoid copepods and its relationship with pollution. Marine Pollution Bulletin 22:72-74.

Moreau, J., and T. Rigaud. 2003. Variable male potential rate of reproduction: high male mating capacity as an adaptation to parasite-induced excess of females? Proceedings of the Royal Society of London B. B 270:1535-1540. 
Moreau, J., A. Bertin, Y. Caubet, and T. Rigaud T. 2001. Sexual selection in an isopod with Wolbachia-induced sex reversal: males prefer real females. Journal of Evolutionary Biology 14:388-394.

Naylor, C., and J. Adams. 1987. Sexual dimorphism, drag constraints and male performance in Gammarus duebeni (Amphipoda). Oikos 48:23-27.

Naylor, C., J. Adams, and P. Greenwood. 1988. Population-dynamics and adaptive sexual strategies in a brackish water crustacean, Gammarus duebeni. Journal of Animal Ecology 57:493-507.

Nicholls, F. 1730. An account of the hermaphrodite lobster presented to the royal society on Thursday May the 7th, by Mr. Fisher of Newgate-Market, examined and dissected, pursuant to an order of the society. Pages 290-294 in F. Nicholls and M. D. Proel, editors. Anat. Oxon. F. R. S. Philosophical Transactions (1683-1775), Volume 36.

Norris, D. O., and J.A. Carr (Eds.). 2005. Endocrine disruption: biological bases for health effects in wildlife and humans. Oxford University Press.

Oetken, M., J. Bachmann U. Schulte-Oehlmann, and J. Oehlmann. 2004. Evidence for endocrine disruption in invertebrates. International Review of Cytology 236:1-44.

Olmstead, A.W., and G.A. LeBlanc. 2002. The juvenoid hormone methyl farnesoate is a sex determinant in the crustacean Daphnia magna. Journal of Experimental Zoology 293:736-739.

Olmstead, A.W., and G.A. LeBlanc. 2007. The environmental-endocrine basis of gynandromorphism (Intersex) in a crustacean. International Journal of Biological Sciences 3:77-84.

Okland, K. A. 1969. On the distribution and ecology of Gammarus lacustris G.O.Sars in Norway, with notes on its morphology and biology. Nytt Magasin for Zoologi 17:111152. 
Parker, J.D., M.E. Torchin, R.A. Hufbauer, N.P. Lemoine, C. Alba, D.M. Blumenthal, O. Bossdorf, J.E. Byers, A.M. Dunn, R.W. Heckman, M. Hejda, V. Jarosik, A.R. Kanarek, L.B. Martin, S.E. Perkins, P. Pysek, K. Schierenbeck, C. Schloeder, R. van Klinken, K.J. Vaughn, W. Williams, and L.M. Wolfe. 2013. Do invasive species perform better in their new ranges? Ecology 94:985-994.

Perrot-Minnot, M..J., M. Gaillard, R. Dodet, and F. Cezilly. 2011. Interspecific differences in carotenoid content and sensitivity to UVB radiation in three acanthocephalan parasites exploiting a common intermediate host. International Journal for Parasitology 41:173181.

Reinhard, E.G. 1956. Parasitic castration of Crustacea. Parasitology 5:79-107.

Rigaud, T. 1997. Inherited microorganisms and sex determination of the hosts, Pages 81-101 in S. L. O’Neill, A. A. Hoffmann, and J. H. Werren, editors. Influential Passengers: Inherited Microorganisms and Arthropod Reproduction. Oxford University Press, Oxford, UK.

Rigaud, T., and P. Juchault. 1992. Genetic control of the vertical transmission of a cytoplasmic sex factor in Armadillidium vulgare Latr. (Crustacea, Oniscidea). Heredity $68: 47-52$.

Rigaud, T., and P. Juchault. 1993. Conflict between feminizing sex ratio distorters and an autosomal masculinizing gene in the terrestrial isopod Armadillidium vulgare Latr. Genetics 133:247-252.

Rigaud, T., and P. Juchault. 1998. Sterile intersexuality in an isopod induced by the interaction between a bacterium (Wolbachia) and the environment. Canadian Journal of Zoology 76:493-499. 
Rigaud, T., D. Bouchon, C. Souty-Grosset, and R. Raimond. 1999a. Mitochondrial DNA polymorphism, sex ratio distorters and population genetics in the isopod Armadillidium vulgare. Genetics, 152:1669-1677.

Rigaud, T., J. Moreau, and P. Juchault. 1999b. Wolbachia infection in the terrestrial isopod Oniscus asellus: sex ratio distortion and effect on fecundity. Heredity 83: 469-475.

Rigaud, T., P. Juchault, and J.P. Mocquard. 1997. The evolution of sex determination in isopod crustaceans. Bioessays 19:409-416.

Rigaud, T., and J. Moreau 2004. A cost of Wolbachia-induced sex reversal and female-biased sex-ratios: decrease in female fertility after sperm depletion in a terrestrial isopod. Proceedings of the Royal Society of London B.271:1941-1946.

Rodgers-Gray, T.P., J.E. Smith, A.E. Ashcroft, R.E. Isaac, and A.M. Dunn. 2004. Mechanisms of parasite-induced sex reversal in Gammarus duebeni. International Journal for Parasitology 34:747-753.

Rubiliani, R. 1985. Response by two species of crabs to a rhizocephalan extract. Journal of Invertebrate Pathology 45:304-310.

Rubiliani, R., and G.O. Godette. 1981. Radiochemical and electrophoretic studies on the CNS of crabs parasitized with rhizocephalans; comparison with healthy crabs. Comparative Biochemistry and Physiology 70B:415-419.

Rubiliani, R., and G. Payen 1979. Modalité de la destruction des régions neurosécrétrices des crabes Carcinus maenas (L.) et $C$. mediterraneus Czerniavsky infestés par la Sacculine. General and Comparative Endocrinology 38:215-228.

Sanchez, M.I., N.O. Rode, E. Flaven, S. Redon, F. Amat, G.P. Vasileva, and T. Lenormand. 2012. Differential susceptibility to parasites of invasive and native species of Artemia living in sympatry: consequences for the invasion of A. franciscana in the Mediterranean region. Biological Invasions 14:1819-1829. 
Sanderson, J. M., 1973. A catalogue of the Amphipoda (Crustacea) in the collection of the late D. M. Reid, now in the Royal Scottish Museum, Edinburgh. Royal Scottish Museum Information Series 79.

Sexton, E. W. 1924. The moulting and growth-stages of Gammarus, with descriptions of the normals and intersexes of G. cheureuxi. Journal of the Marine Biological Association of the UK 13:340-401.

Sexton, E. W., 1911. The Amphipoda collected by the 'Huxley' from the North side of the Bay of Biscay in August, 1906. Journal of the Marine Biological Association of the UK 9:199.

Sexton, E. W., 1939. On a new species of Gammarus (G. tiginus) from Droitwich District. Journal of the Marine Biological Association of the UK 23:543-551.

Shields, J.D., and J. Gomez-Gutierrez. 1996. Oculophryxus bicaulis, a new genus and species of dajid isopod parasitic on the euphausiid Stylocheiron affine Hansen. International Journal for Parasitology 26:261-268.

Short, S., G. Yang, P., and A.T. Ford. 2012. A widespread and distinctive form of amphipod intersexuality not induced by known feminising parasites. Sexual Development, 6:320324.

Short, S., G. Yang, Y. Guler, A. Green Etxabe, P. Kille, and A.T. Ford. 2014. Crustacean intersexuality is feminization without demasculinization: implications for environmental toxicology. Environmental Science and Technology, 48:13520-13529.

Sicard, M., J. Dittmer, P. Grève, D. Bouchon, and C. Braquart-Varnier. 2014. A host as an ecosystem: Wolbachia coping with environmental constraints. Environmental Microbiology 16:3583-3607.

Skovgaard, A. 2005. Infection with the dinoflagellate parasite Blastodinium spp. in two Mediterranean copepods. Aquatic Microbial Ecology 38:93-101. 
Sloan, D.B., T. Giraud, and M.E. Hood. 2008. Maximized virulence in a sterilizing pathogen: the anther-smut fungus and its co-evolved hosts. Journal of Evolutionary Biology 21:1544-1554.

Sloan, N.A. 1984. Incidence and effects of parasitism by the rhizocephalan barnacle, Briarosaccus callosus Boschma, in the golden king crab, Lithodes aequispina Benedict, from deep fjords in northern British Columbia, Canada. Journal of Experimental Marine Biology and Ecology 84:111-131.

Slothouber Galbreath, J.G.M., J.E. Smith, J.J. Becnel, R.K. Butlin, and A.M. Dunn. 2010. Reduction in post-invasion genetic diversity in Crangonyx pseudogracilis (Amphipoda: Crustacea): a genetic bottleneck or the work of hitchhiking vertically transmitted microparasites? Biological Invasions 12:191-209.

Smith, D.G., 1977. An occurrence of a female intersex of Asellus communis Say (Isopoda, Asellidae). Crustaceana, 32(1):89-90.

Takahashi, T., A. Araki, Y. Nomura, M. Koga, and K. Arizono. 2000. The occurrence of dual-gender imposex in Japanese freshwater crab. Journal of Health Science 46:376379.

Taylor, D.M. 1986. A bilateral gynandromorph of the snow crab, Chionoectes opilio, from Newfoundland, Canada. Crustaceana 51:309-312.

Terry, R.S., A.M. Dunn, and J.E. Smith. 1997. Cellular distribution of a feminizing microsporidian parasite: A strategy for transovarial transmission. Parasitology 115:157163.

Terry, R.S., J.E. Smith, and A.M. Dunn. 1998. Impact of a novel, feminising microsporidium on its crustacean host. Journal of Eukaryotic Microbiology 45:497-501.

Terry, R.S., J.E. Smith, D. Bouchon, T. Rigaud, P. Duncanson, R.G. Sharpe, and A.M. Dunn. 1999a. Ultrastructural characterisation and molecular taxonomic identification of 
Nosema granulosis $\mathrm{n}$. sp., a transovarially transmitted feminising (TTF)

microsporidium. Journal of Eukaryotic Microbiology 46:492-499.

Terry, R.S., A.M. Dunn, and J.E. Smith. 1999b. Segregation of a microsporidian parasite during host cell mitosis. Parasitology 118:43-48.

Terry, R.S., J.E. Smith, R.G. Sharpe, T. Rigaud, D.T.J. Littlewood, J.E. Ironside, D.

Rollinson, D. Bouchon, C. MacNeil, J.T.A. Dick, and A.M. Dunn. 2004. Widespread vertical transmission and associated host sex-ratio distortion within the eukaryotic phylum Microspora. Proceedings of the Royal Society of London Series B-Biological Sciences 271:1783-1789.

Thomas, F., F. Renaud, and F. Cezilly. 1996. Assortative pairing by parasitic prevalence in Gammarus insensibilis (Amphipoda): Patterns and processes. Animal Behaviour $52: 683-690$

Torchin, M.E., K.D. Lafferty, A.P. Dobson, V.J. McKenzie, and A.M. Kuris. 2003. Introduced species and their missing parasites. Nature 421:628-630.

Turra, A., 2004. Intersexuality in hermit crabs: reproductive role and fate of gonopores in intersex individuals. Journal of the Marine Biological Association of the United Kingdon 84:757-759.

Van Wyk, P.M. 1982. Inhibition of the growth and reproduction of the porcellanid crab Pachycheles rudis by the bopyrid isopod, Aporobopyrus muguensis. Parasitology $85: 459-473$

Vandenbergh, G.F., D. Adriaens, T. Verslycke, and C.R. Janssen 2003. Effects of 17bethinylestradiol on sexual development of the amphipod Hyalella azteca. Ecotoxicology and Environmental Safety 54:216-222. 
Verne, S., M. Johnson, D. Bouchon, and F. Grandjean. 2012. Effects of parasitic sex-ratio distorters on host genetic structure in the Armadillidium vulgare-Wolbachia association. Journal of Evolutionary Biology 25:264-276.

Warner, D.A., and R. Shine. 2008. The adaptive significance of temperature-dependent sex determination in a reptile. Nature 451:566-U5.

Wattier, R.A., E.R. Haine, J. Beguet, G. Martin, L. Bollache, I.B. Muskó, D. Platvoet, and T. Rigaud. 2007. No genetic bottleneck or associated microparasite loss in invasive populations of a freshwater amphipod. Oikos 116:1941-1953.

Weedall, R.T., M. Robinson, J.E. Smith, and A.M. Dunn. 2006. Targeting of host cell lineages by vertically transmitted, feminising microsporidia. International Journal for Parasitology 36:749-756.

Wolff, C. and G. Scholtz. 2002. Cell Lineage, Axis Formation, and the Origin of Germ Layers in the Amphipod Crustacean Orchestia cavimana. Developmental Biology 250:44-58

Yaldwyn, J.C., 1966. Protandrous hermaphroditism in decapod prawns of the families Hippolytidae and Campylonotidae. Nature, London 209:1366.

Yang, G., P. Kille, and A.T. Ford. 2008. Infertility in a marine crustacean: Have we been ignoring pollution impacts on male invertebrates? Aquatic Toxicology 88:81-87.

Yang, G., S. Short, P. Kille, P., and A.T.Ford. 2011. Microsporidia infections in the amphipod, Echinogammarus marinus (Leach): suggestions of varying causal mechanisms to intersexuality. Marine Biology 158:461-470.

Zelmer, D.A., and G.W. Esch. 1998. Interactions between Halipegus occidualis and its ostracod second intermediate host: evidence for castration? Journal of Parasitology 84:778-782. 
Zimmermann, B.L., D. Bouchon, M.P. Almerao, and P.B. Araujo. 2015. Wolbachia in Neotropical terrestrial isopods. FEMS Microbiol Ecology 91:fiv025. 

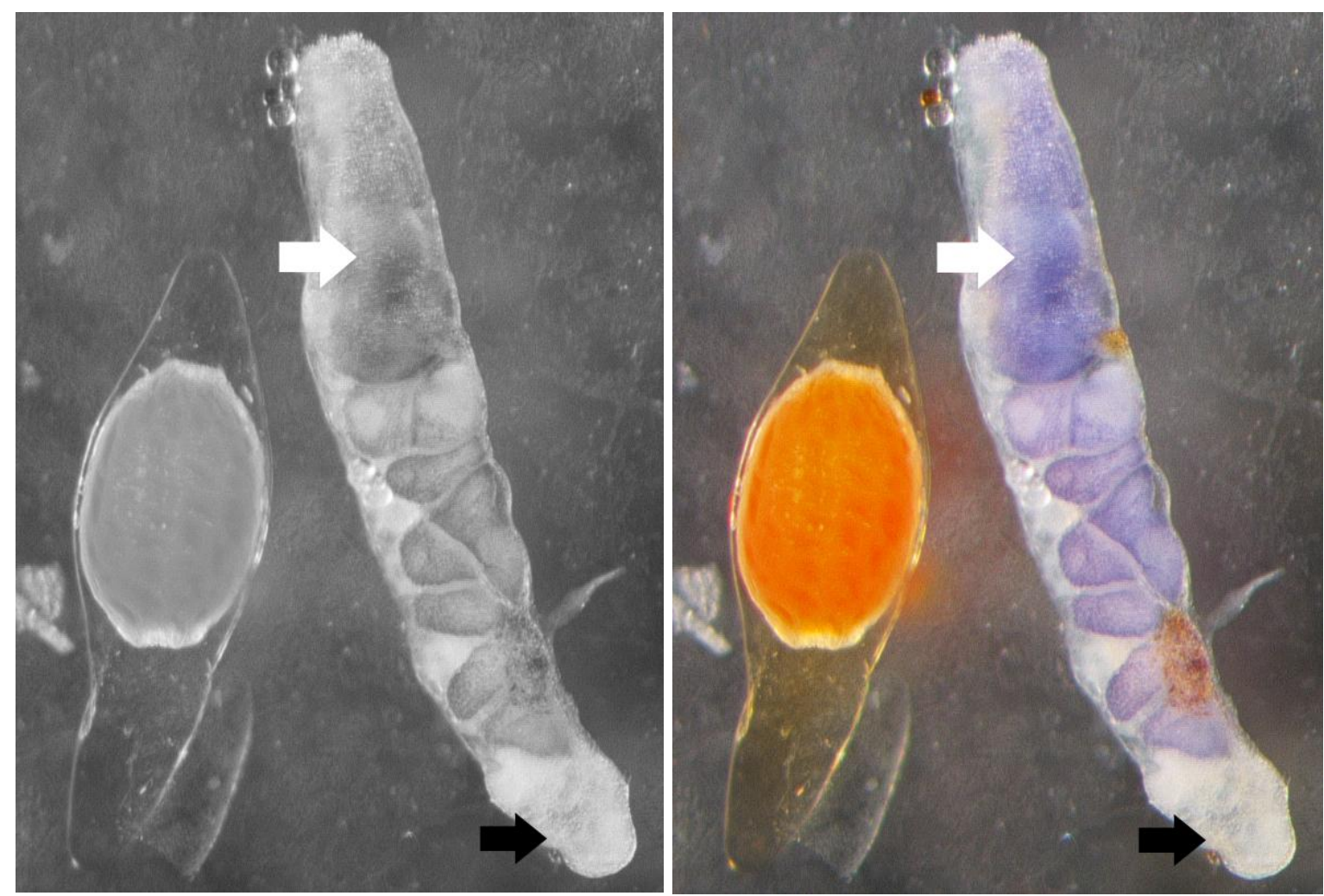

Fig. 14.1. Cystacanth stage of the acanthocephalan parasite Polymorphus minutus (left) and of the castrated ovary dissected from the Gammarus pulex female where the parasite was found (right). The white arrow denotes a zone of the ovary where oocytes are welded in a single shapeless mass. The black arrow denotes a zone of the ovary where no developing oocytes can be distinguished. Between these two zones, distinguishable oocytes are of an abnormal blue colour, contrasting with the brownish colour of developing oocytes in an uninfected female. These oocytes will never be laid. Photo credit: Yann Bailly, Laboratory Biogéosciences, Dijon, France. 


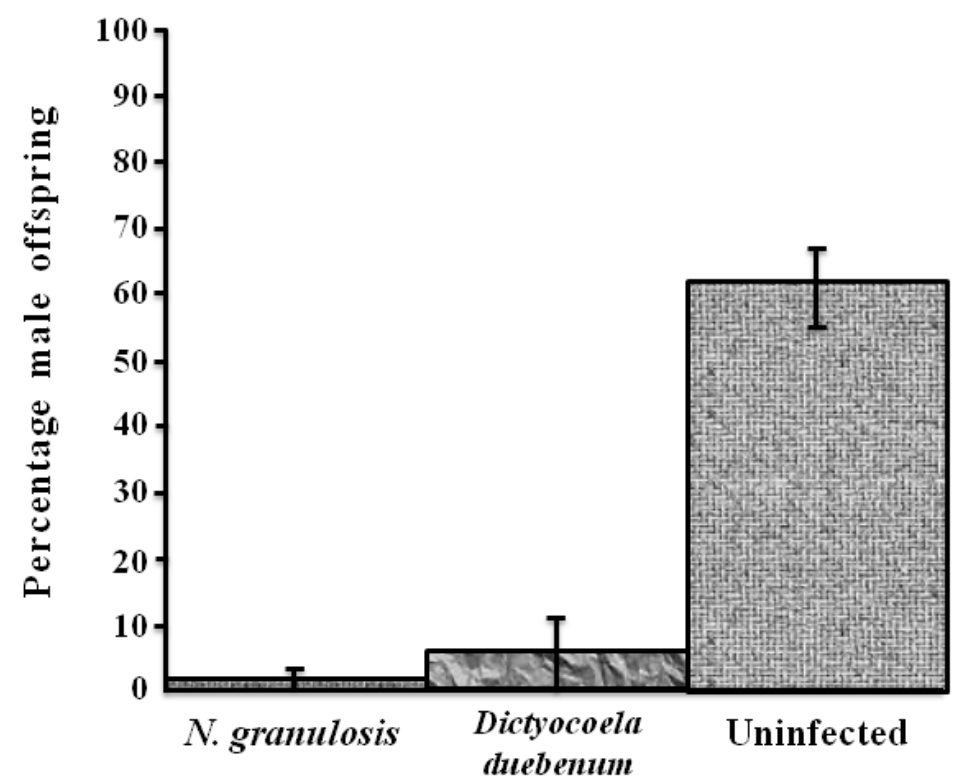

Fig. 14.2. Mean sex ratios of offspring produced by Gammarus duebeni females infected with Nosema granulosis, females infected with Dictyocoela duebenum, and uninfected females. Survival did not differ between infected and uninfected broods. The heights of the bars indicate the mean percentages of male offspring produced by females in each category. The error bars indicate \pm 1 SE. Modified from Ironside et al. (2003) with permission from Wiley and Sons. 
A
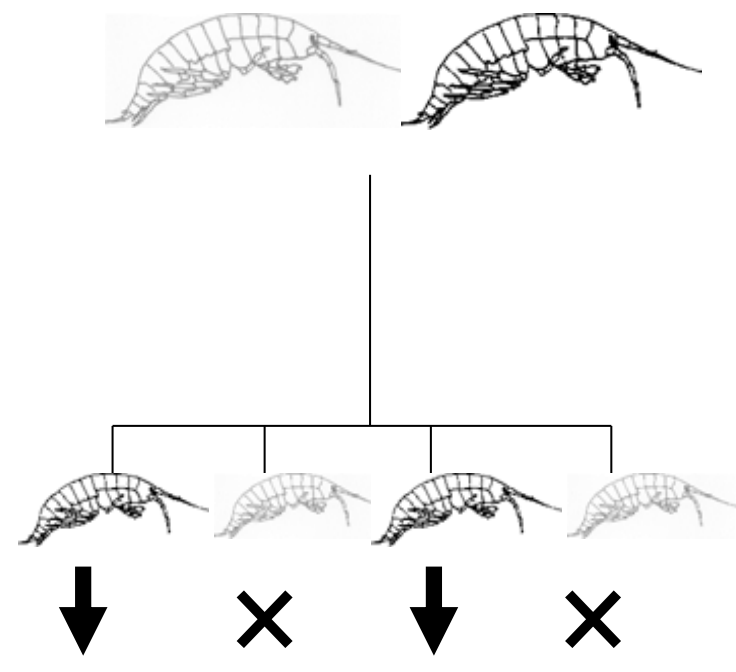

B
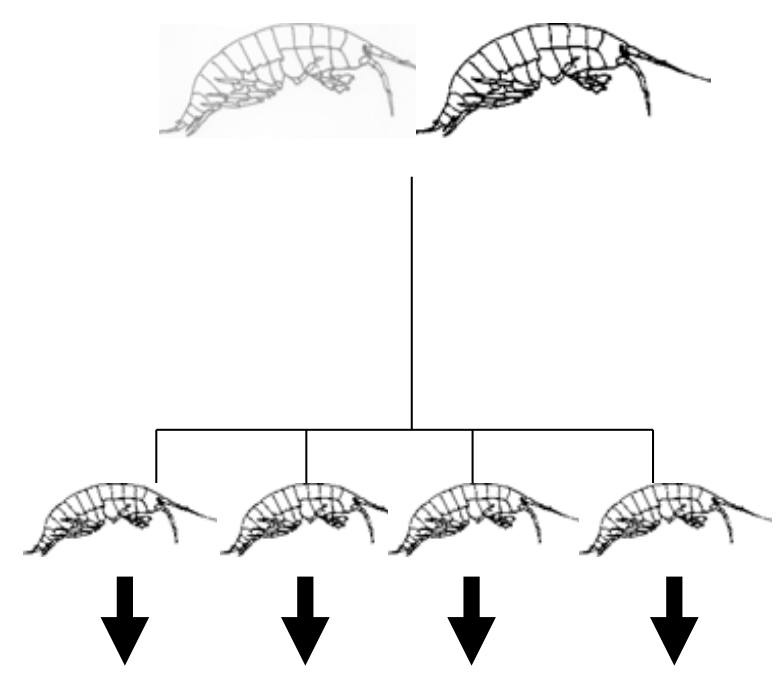

Fig. 14.3. Vertically transmitted parasites are transmitted from parent to offspring via the gamete. Males are gray and females are black. Difference in gamete size between sexes means that vertical transmission is usually only maternal, and that males are a transmission dead-end for the parasite (A). By converting male offspring to females, feminizing parasites increase the relative frequency of the transmitting (female) sex (B). 

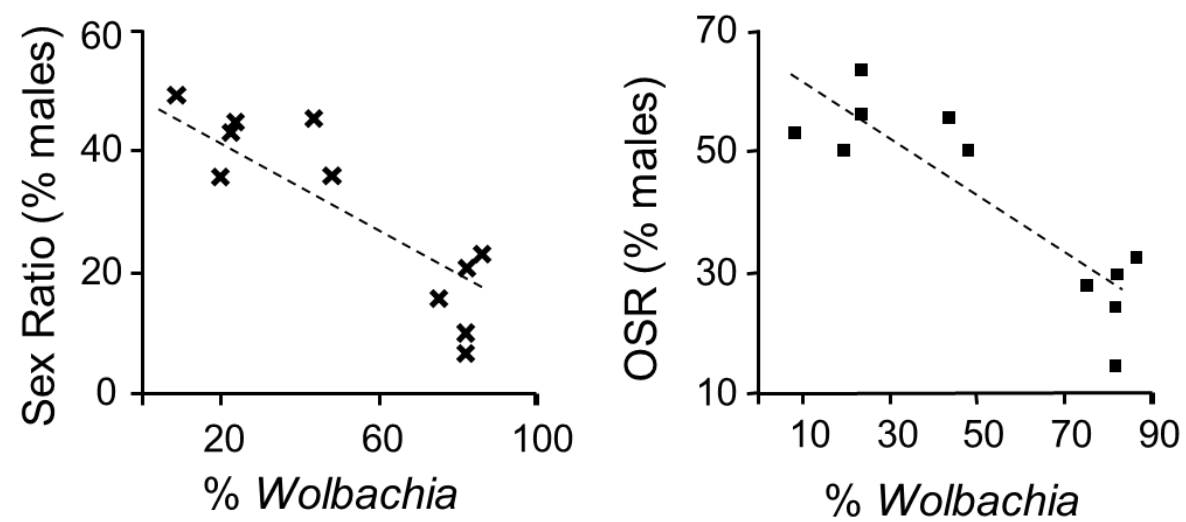

Fig. 14.4. Population sex ratio (Left) and operational sex ratio (OSR, i.e., the proportion of males vs. females receptive to mating) (Right), as a function of Wolbachia prevalence (proportion of infected females) among populations of the terrestrial isopod Philoscia muscorum. High prevalence of Wolbachia is linked with strong deficits in males, but due to high mating capacity of males, all receptive females were inseminated. Redrawn from Moreau and Rigaud (2003). 


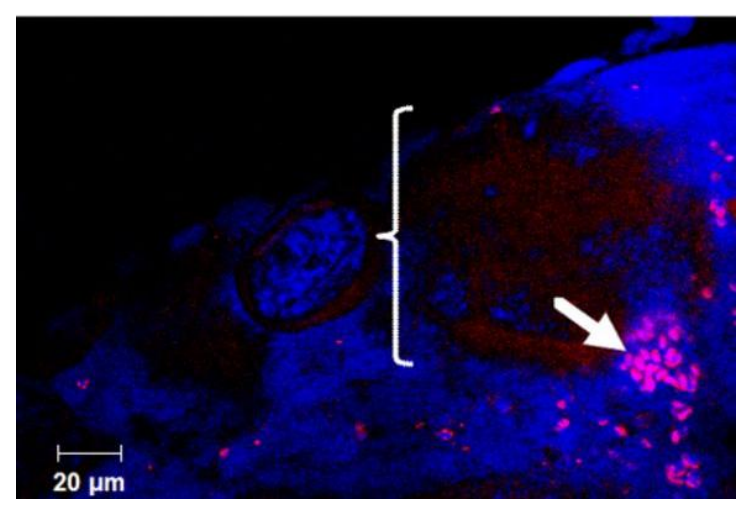

Fig. 14.5. A Gammarus duebeni follicle cell containing Dicytocoelum duebenum spores (arrow) is visible in the vicinity of a maturing oocyte (bracket). Oocyte yolk (bracket) is lightly autofluorescent. From Dubuffet et al. (2013), with permission from the American Society for Microbiology.

Black and white version of Fig. 5

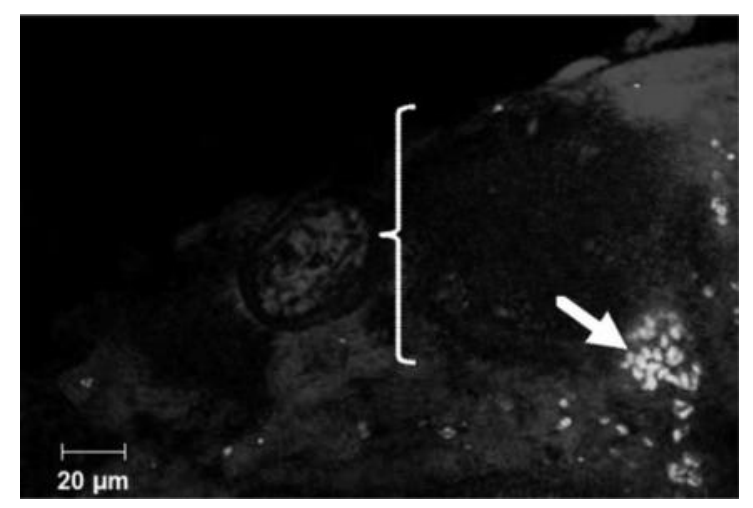




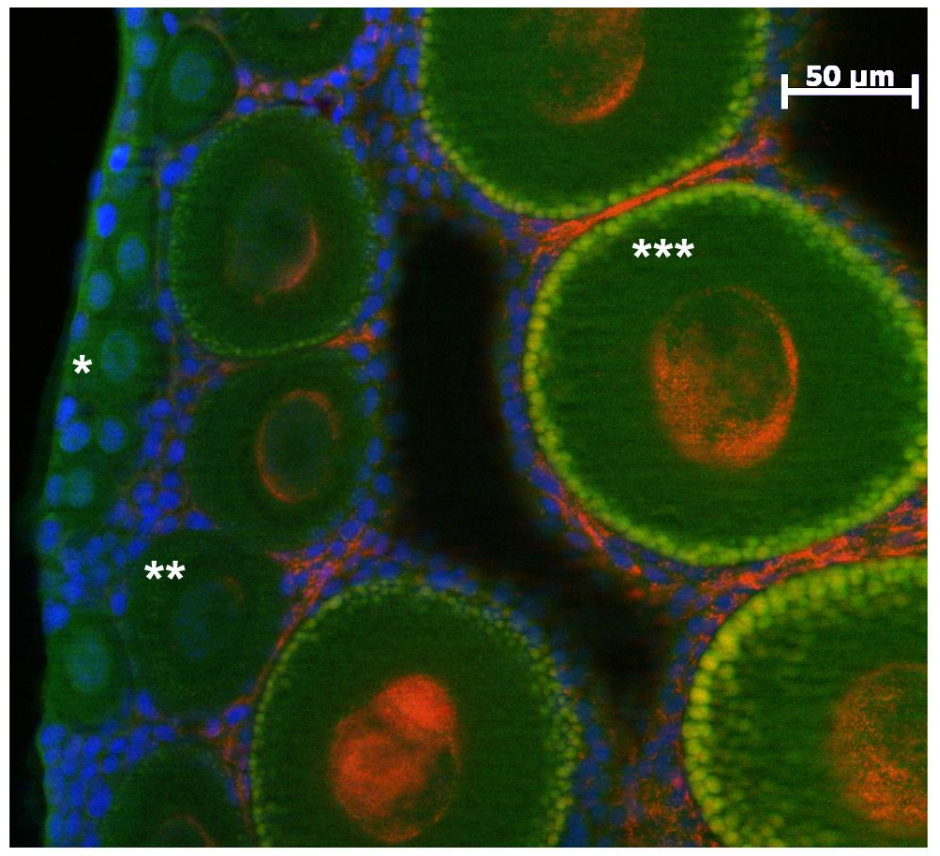

Fig. 14.6. Wolbachia distribution in an infected ovary of an Armadillidium vulgare female, illustrating the apparent progressive colonization of oocytes during their maturation.

Wolbachia (in red) appear are mostly distributed around the oocyte nuclei. The germarium, where oocytes are differentiating, is on the left side. Most of the young, recently differentiated, oocytes are uninfected $(*)$, medium-sized oocytes are weakly infected $(* *)$ and mature oocytes are highly infected (***). Figure from Genty et al. (2014), under License CCBY.doi:10.1371/journal.pone.0094577.g005. 
Black and white version of Fig. 6

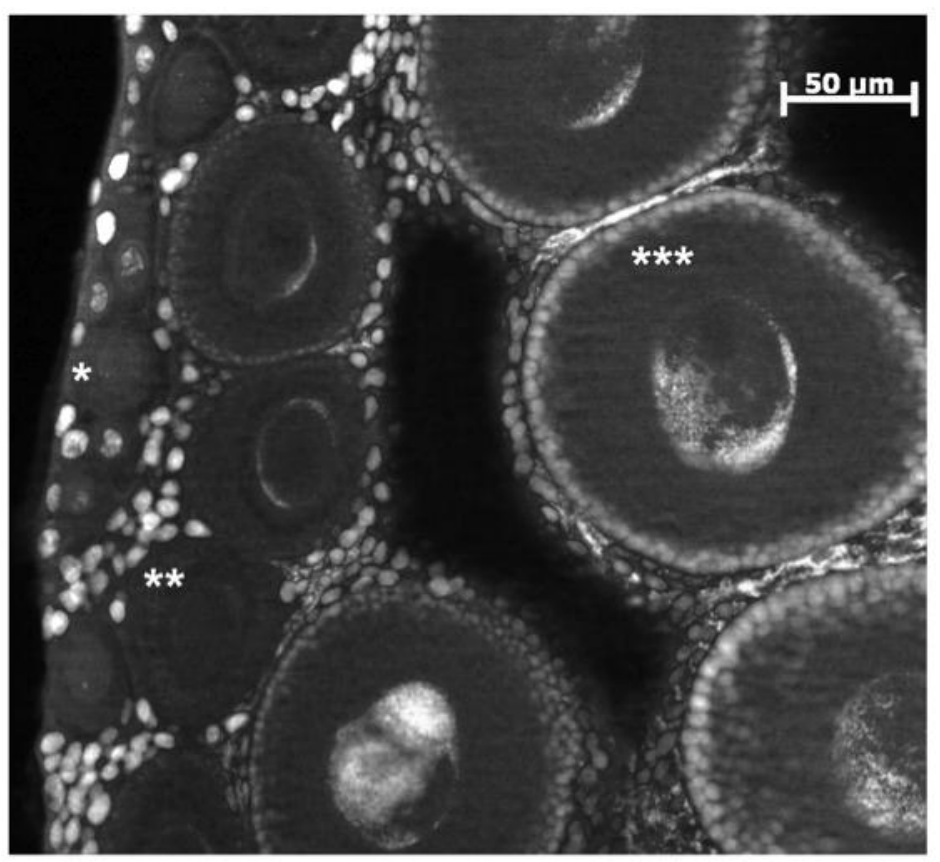

Fig. 14.6. Wolbachia distribution in an infected ovary of an Armadillidium vulgare female, illustrating the apparent progressive colonization of oocytes during their maturation.

Wolbachia appear are mostly distributed around the oocyte nuclei (appearing here as bright white dots ou cloud surrounding nuclei). The germarium, where oocytes are differentiating, is on the left side. Most of the young, recently differentiated, oocytes are uninfected $(*)$, medium-sized oocytes are weakly infected $(* *)$ and mature oocytes are highly infected (***). Figure from Genty et al. (2014), doi:10.1371/journal.pone.0094577.g005 under License CCBY. 


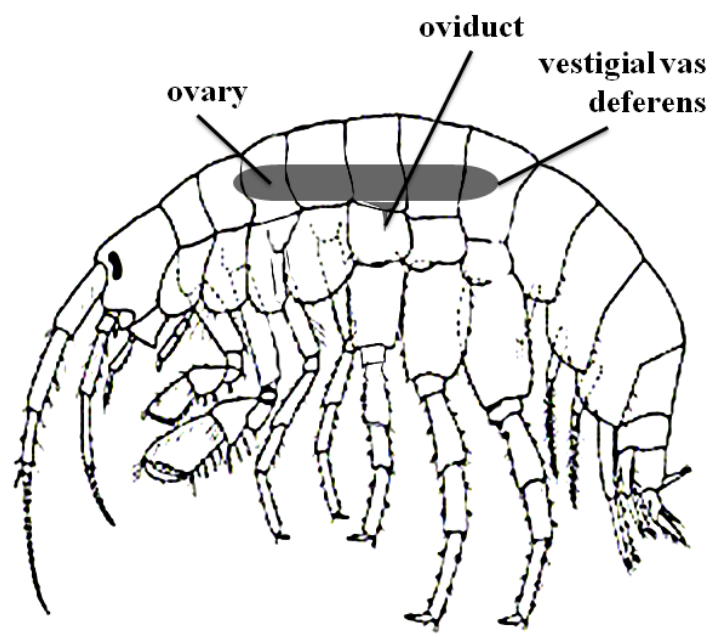

Fig. 14.7. Line drawing of the gonad of a N. granulosis-infected intersex Gammarus duebeni. Structures shown are ovary, oviduct, and vestigial vas deferens. Redrawn from Rodgers-Gray et al. (2004), with permission from Elsevier. 
Table 14.1. Overview of crustacean host taxa that are "victims" of castration and their castrator parasite taxa (examples of species are given; in most taxa, more species are involved).

\begin{tabular}{|c|c|c|c|c|c|}
\hline Hosts taxa and species & Parasite taxa & Parasite species & $\begin{array}{l}\text { Type of } \\
\text { castration }\end{array}$ & Comments & References \\
\hline \multicolumn{6}{|l|}{$\begin{array}{c}\text { Branchiopoda } \\
\text { Anostraca }\end{array}$} \\
\hline $\begin{array}{l}\text { Artemia } \\
\text { parthenogenetica }\end{array}$ & Cestoda & $\begin{array}{l}\text { Flamingolepis } \\
\text { liguloides }\end{array}$ & TPC & & Sanchez et al. 2012 \\
\hline $\begin{array}{l}\text { Artemia } \\
\text { parthenogenetica }\end{array}$ & Cestoda & $\begin{array}{l}\text { Flamingolepis } \\
\text { flamingo }\end{array}$ & RF & & Sanchez et al. 2012 \\
\hline Cladocera & & & & & \\
\hline Daphnia pulicaria & $\begin{array}{l}\text { Fungi, } \\
\text { Chytridiomycota }\end{array}$ & Polycaryum leave & TPC & & Johnson et al. 2006 \\
\hline Daphnia magna & Microsporidia & $\begin{array}{l}\text { Flabelliforma } \\
\text { magnivora }\end{array}$ & TPC? & & $\begin{array}{l}\text { Decaestecker et al. } \\
2005\end{array}$ \\
\hline Daphnia magna & Bacteria & Pasteuria ramosa & TPC & $\begin{array}{l}\text { Infection induces gigantism; impacts } \\
\text { population dynamics of the host }\end{array}$ & $\begin{array}{l}\text { Ebert et al. 2004, } \\
\text { Decaestecker et al. } \\
2005\end{array}$ \\
\hline \multicolumn{6}{|l|}{ Ostracoda } \\
\hline Cypridopsis sp. & Trematoda & Halipegus occidualis & RF & $\begin{array}{l}\text { Reduction of host fecundity is } \\
\text { intensity dependent; hosts have an } \\
\text { increased longevity }\end{array}$ & $\begin{array}{l}\text { Zelmer and Esch } \\
1998\end{array}$ \\
\hline \multicolumn{5}{|l|}{ Copepoda } & Skovgaard 2005 \\
\hline \multicolumn{6}{|l|}{ Amphipoda } \\
\hline Corophium volutator & Trematoda & Gynaecotyla adunca & $\mathrm{RF}$ & $\begin{array}{l}\text { The reduction of host fecundity is } \\
\text { intensity dependent }\end{array}$ & McCurdy et al. 1999 \\
\hline \multicolumn{6}{|l|}{ Gammaridea } \\
\hline Gammarus pulex & Acanthocephala & $\begin{array}{l}\text { Pomphorhynchus } \\
\text { laevis }\end{array}$ & $\mathrm{RF}, \mathrm{BC}$ & & $\begin{array}{l}\text { Bollache et al. 2001, } \\
2002\end{array}$ \\
\hline
\end{tabular}




\begin{tabular}{|c|c|c|c|c|}
\hline Gammarus pulex & Acanthocephala & Polymorphus minutus & TPC, BC & $\begin{array}{l}\text { Bollache et al. 2001, } \\
2002\end{array}$ \\
\hline Gammarus pulex & Cestoda & $\begin{array}{l}\text { Cyathocephalus } \\
\text { truncatus }\end{array}$ & $\mathrm{RF}, \mathrm{BC}$ & Galipaud et al. 2011 \\
\hline
\end{tabular}

\section{Isopoda \\ Anthuridea}

Cyathura carinata

Trematoda Unknown

$\mathrm{RF}, \mathrm{BC}$ ?

Fewer ovigerous females are found

Ferreira et al. 2005

among infected than uninfected

females

\section{Aselotta}

Asellus aquaticus

Acanthocephala

Acanthocephalus

TPC?

Brattey 1983

lucii

\section{Euphausiacea}

Stylocheiron afine

Isopoda, Dajidae

Oculophryxus

TPC

Shields and Gomez-

Decapoda

\section{Thalassinidea}

Upogebia pugettensis

Isopoda, Bopyridae Orthione griffenis

TPC

Invasive parasite; may cause host Gutierrez 1996

\section{Dendrobranchiata}

Parapenaeopsis stylifera Isopoda, Bopyridae Epipenaeon ingens

TPC

population collapses

Dumbauld et al. 2011

\section{Caridea}

Lysmata amboinensis

Lysmata seticaudata

Palaemon serratus

Isopoda, Bopyridae

Isopoda, Bopyridae

Fecampiida

Parabopyrella sp.

RF

Eophryxus lysmatae TPC

Fecampia

TPC?

\section{Anomura}

Pachycheles rudis

(Plathelminthes)

erythrocephala

Isopoda, Bopyridae Aporobopyrus

muguensis

\section{Gopalakrishnan et al.} 2009

Calado et al. 2006

Calado et al. 2005

Bellon-Humbert 1983

Van Wyk 1982 
Brachyura

Carcinus maenas

Rhizocephala

Sacculina carcini

TPC

Castrated males behave like females (e.g., brooding behavior)

TPC?

erythrocephala

Clistosaccus paguri TPC

Pagurus bernhardus

(plathelminthes)

Rhizocephala

Nectonema agile e.g., Rubiliani and

Payen 1979,

Kristensen et al. 2012

McDermott et al.

2010

McDermott et al.

2010

McDermott et al. 2010

TPC: total physiological castration (no clutch, either destruction or disruption of gonad functioning, mostly in females). RF: reduction in fertility or fecundity (partial castration), BC: behavioral castration, ?: the nature of castration is uncertain. 
Table 14.2 Intersexuality in amphipod and isopod Crustacea

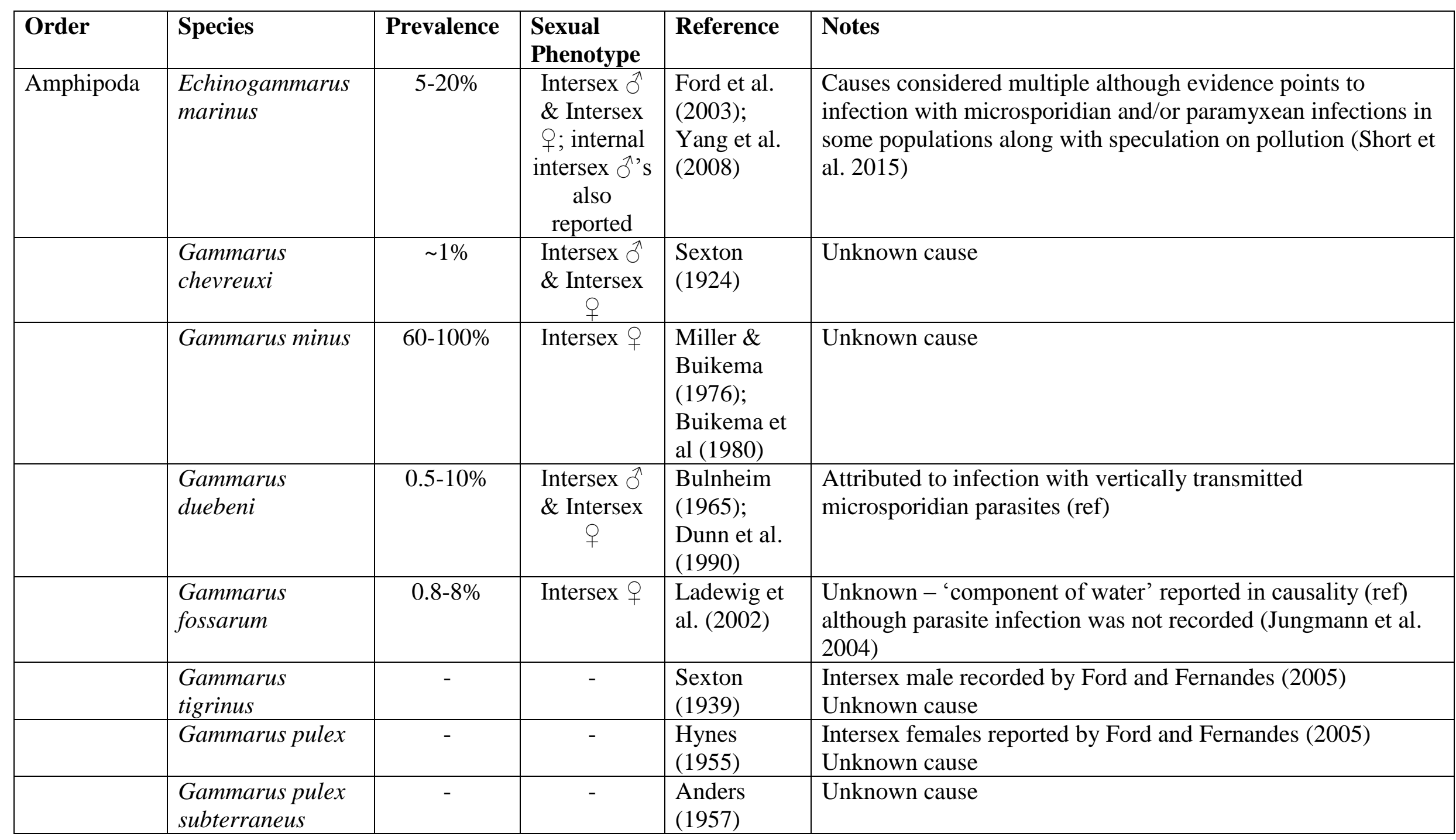




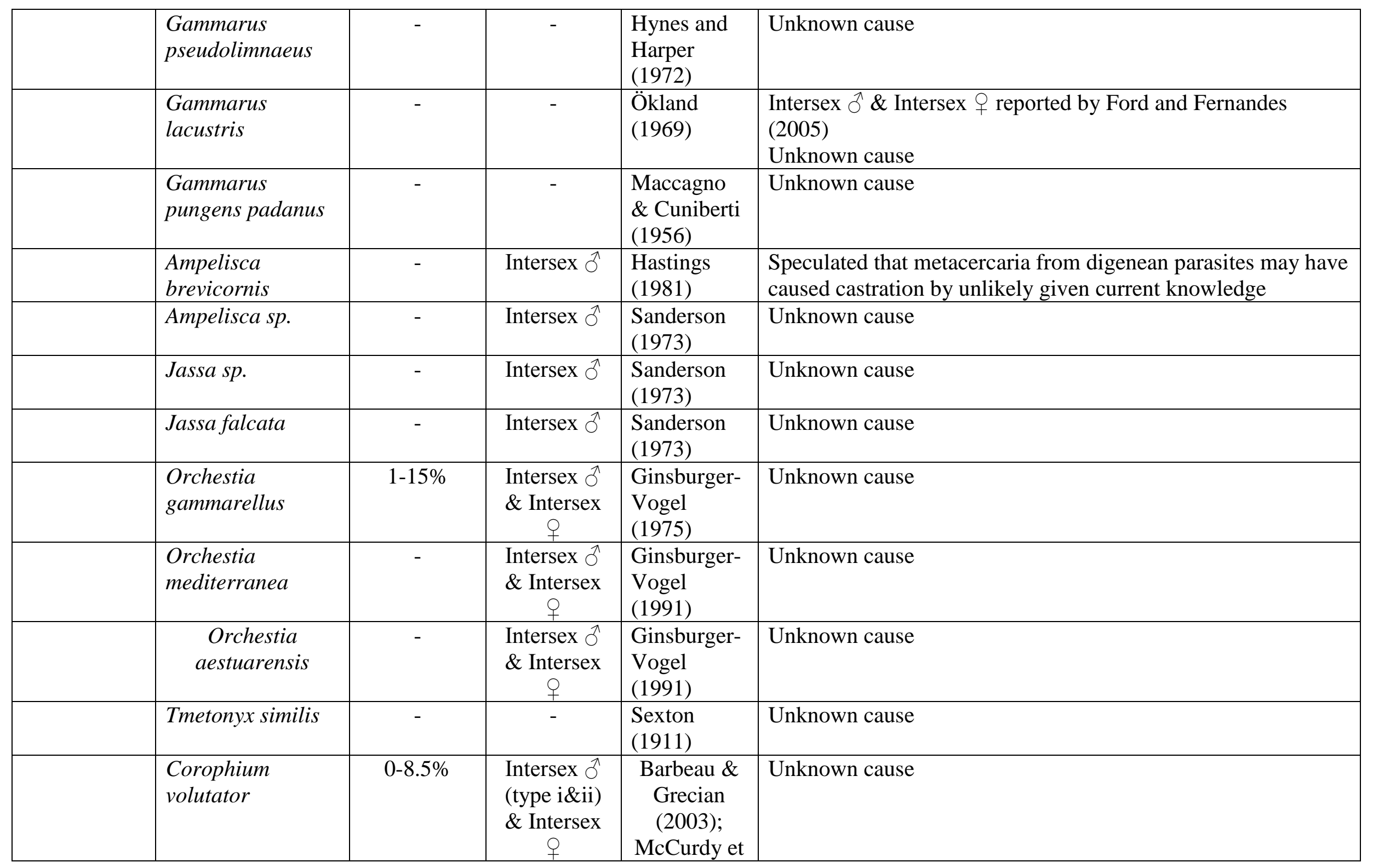




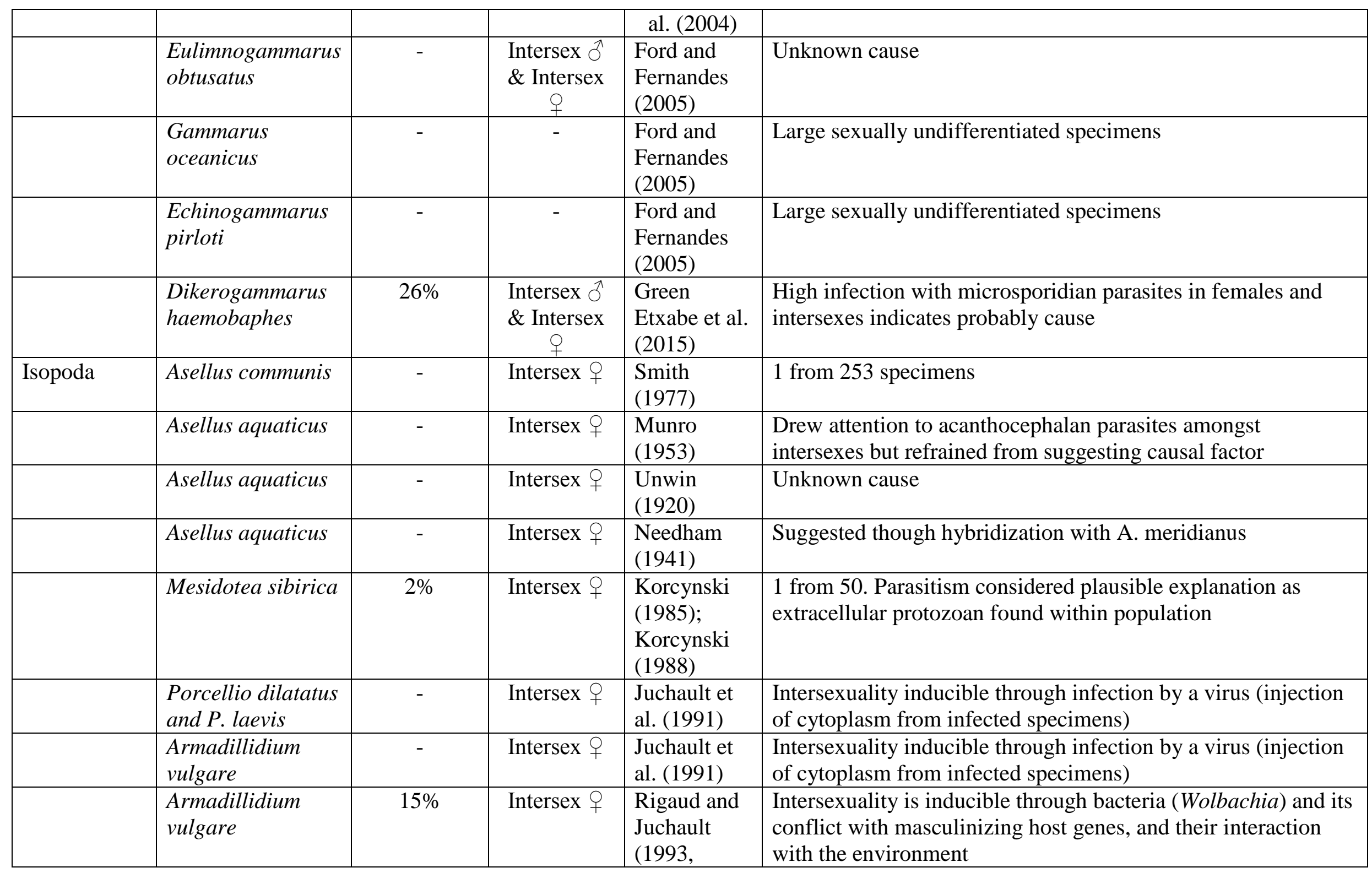




\begin{tabular}{|l|l|l|l|l|l|}
\hline & & & $1998)$ & \\
\hline & $\begin{array}{l}\text { Sphaeroma } \\
\text { rugicauda }\end{array}$ & - & Intersex q & $\begin{array}{l}\text { Martin et al. } \\
(1994)\end{array}$ & $\begin{array}{l}\text { Intersexuality is linked with intracytoplasmic bacterial } \\
\text { infection (Wolbachia) }\end{array}$ \\
\hline & Idotea balthica & $\begin{array}{l}\text { Mocquard et } \\
\text { al. (1978) }\end{array}$ & Intersexuality is inducible by variation in the environment \\
\hline & Ligia oceanica & $\begin{array}{l}\text { Martin et al. } \\
(1974)\end{array}$ & $\begin{array}{l}\text { Intersexuality is linked with intracytoplasmic bacterial } \\
\text { infection }\end{array}$ \\
\hline & $\begin{array}{l}\text { Chaetophiloscia } \\
\text { elongata }\end{array}$ & $\begin{array}{l}\text { Dalens } \\
(1968)\end{array}$ & Unknown cause \\
\hline
\end{tabular}

